University of Nebraska - Lincoln

DigitalCommons@University of Nebraska - Lincoln

\title{
Abandoned Mine Drainage in the Swatara Creek Basin, Southern Anthracite Coalfield, Pennsylvania, USA: 1. Stream Water Quality Trends Coinciding with the Return of Fish
}

\author{
Charles A. Cravotta III \\ US Geological Survey, PA Water Science Center, 215 Limekiln Rd, New Cumberland, PA, USA, \\ cravotta@usgs.gov \\ Robin A. Brightbill \\ USGS PA Water Science Center, New Cumberland, PA 17070, USA \\ Michael J. Langland \\ USGS PA Water Science Center, New Cumberland, PA 17070, USA
}

Follow this and additional works at: https://digitalcommons.unl.edu/usgsstaffpub

Part of the Earth Sciences Commons

\begin{abstract}
Cravotta III, Charles A.; Brightbill, Robin A.; and Langland, Michael J., "Abandoned Mine Drainage in the Swatara Creek Basin, Southern Anthracite Coalfield, Pennsylvania, USA: 1. Stream Water Quality Trends Coinciding with the Return of Fish" (2010). USGS Staff -- Published Research. 291.

https://digitalcommons.unl.edu/usgsstaffpub/291
\end{abstract}

This Article is brought to you for free and open access by the US Geological Survey at DigitalCommons@University of Nebraska - Lincoln. It has been accepted for inclusion in USGS Staff -- Published Research by an authorized administrator of DigitalCommons@University of Nebraska - Lincoln. 


\title{
Abandoned Mine Drainage in the Swatara Creek Basin, Southern Anthracite Coalfield, Pennsylvania, USA: 1. Stream Water Quality Trends Coinciding with the Return of Fish
}

\author{
Charles A. Cravotta III • Robin A. Brightbill • \\ Michael J. Langland
}

Received: 14 September 2009/ Accepted: 1 April 2010

(C) US Government 2010

\begin{abstract}
Acidic mine drainage (AMD) from legacy anthracite mines has contaminated Swatara Creek in eastern Pennsylvania. Intermittently collected base-flow data for 1959-1986 indicate that fish were absent immediately downstream from the mined area where $\mathrm{pH}$ ranged from 3.5 to 7.2 and concentrations of sulfate, dissolved iron, and dissolved aluminum were as high as $250,2.0$, and $4.7 \mathrm{mg} / \mathrm{L}$, respectively. However, in the 1990s, fish returned to upper Swatara Creek, coinciding with the implementation of AMD treatment (limestone drains, limestone diversion wells, limestone sand, constructed wetlands) in the watershed. During 1996-2006, as many as 25 species of fish were identified in the reach downstream from the mined area, with base-flow $\mathrm{pH}$ from 5.8 to 7.6 and concentrations of sulfate, dissolved iron, and dissolved aluminum as high as $120,1.2$, and $0.43 \mathrm{mg} / \mathrm{L}$, respectively. Several of the fish taxa are intolerant of pollution and low $\mathrm{pH}$, such as river chub (Nocomis micropogon) and longnose dace (Rhinichthys cataractae). Cold-water species such as brook trout (Salvelinus fontinalis) and warm-water species such as rock bass (Ambloplites rupestris) varied in predominance depending on stream flow and stream temperature. Storm flow data for 1996-2007 indicated pH, alkalinity, and sulfate concentrations decreased as the stream flow and associated storm-runoff component increased, whereas iron and other metal concentrations were poorly correlated with stream flow because of hysteresis effects (greater metal concentrations during rising stage than falling stage). Prior to $1999, \mathrm{pH}<5.0$ was recorded during several storm events; however, since the implementation of AMD treatments, $\mathrm{pH}$ has been maintained near neutral. Flow-adjusted trends for
\end{abstract}

C. A. Cravotta III $(\bowtie) \cdot$ R. A. Brightbill $\cdot$ M. J. Langland

USGS PA Water Science Center, New Cumberland,

PA 17070, USA

e-mail: cravotta@usgs.gov
1997-2006 indicated significant increases in calcium; decreases in hydrogen ion, dissolved aluminum, dissolved and total manganese, and total iron; and no change in sulfate or dissolved iron in Swatara Creek immediately downstream from the mined area. The increased $\mathrm{pH}$ and calcium from limestone in treatment systems can be important for mitigating toxic effects of dissolved metals. Thus, treatment of AMD during the 1990s improved $\mathrm{pH}$ buffering, reduced metals transport, and helped to decrease metals toxicity to fish.

Keywords Acidification - Acid mine drainage .

Aquatic restoration $\cdot$ Fish $\cdot$ Metals $\cdot$ Storm flow $\cdot$ Sulfate

\section{Introduction}

Drainage from abandoned mines affects the water quality and aquatic ecology of streams and lakes in coal and metal mining regions worldwide (Nordstrom 2000; Wolkersdorfer and Bowell 2004). In the Appalachian coalfield of the eastern USA, acidic mine drainage (AMD) from legacy mines has rendered many streams fishless (Herlihy et al. 1990). In Pennsylvania, AMD from abandoned coal mines is the leading cause of nonpoint-source (NPS) pollution, degrading approximately $8,800 \mathrm{~km}$ of streams (Pennsylvania Dept of Environmental Protection 2004, 2007) and accounting for lost revenues of approximately $\$ 93$ million annually because of recreational fishing losses (Pennsylvania Dept of Environmental Protection 2009).

Effects of AMD are complex but can be categorized as acidity, metal toxicity, sedimentation, and salinization. AMD commonly has acidic pH $(<4.5)$ and elevated concentrations of sulfate $\left(\mathrm{SO}_{4}^{2-}\right)$, iron $\left(\mathrm{Fe}^{2+}, \mathrm{Fe}^{3+}\right)$, aluminum $\left(\mathrm{Al}^{3+}\right)$, manganese $\left(\mathrm{Mn}^{2+}\right)$, zinc $\left(\mathrm{Zn}^{2+}\right)$, nickel $\left(\mathrm{Ni}^{2+}\right)$, copper $\left(\mathrm{Cu}^{2+}\right)$, lead $\left(\mathrm{Pb}^{2+}\right)$, and other solutes that result 
from the oxidation of pyrite $(\mathrm{FeS} 2)$ and the subsequent dissolution of aluminosilicate, oxide, and carbonate minerals by acidic water (Blowes et al. 2003; Cravotta 2008; Nordstrom 2000). Low pH and elevated concentrations of dissolved metals in the water column and pore water of stream sediment can be stressful or toxic to fish and aquatic macroinvertebrates (Baker and Schofield 1982; Butler et al. 1973; Courtney and Clements 2002; Dsa et al. 2008; MacDonald et al. 2000; US EPA 2002). The transport of dissolved metals across biological membranes and/or ingestion of contaminated food or sediment with subsequent transport across the gut are the primary routes of toxic exposure (Havas and Rosseland 1995). Additionally, dissolved $\mathrm{Al}^{3+}$ and $\mathrm{Fe}^{3+}$ can precipitate on the gills or equivalent organs, suffocating aquatic organisms (Cleveland et al. 1991; Havas and Rosseland 1995; Henry et al. 1999).

The severity of metals toxicity tends to be greater under low-pH conditions than under near-neutral conditions. Accordingly, the US EPA (2002) recommends pH 6.5-9.0 for protection of freshwater aquatic life, and the Commonwealth of Pennsylvania (2002) stipulates that effluent discharged from active mines must have $\mathrm{pH}$ 6.0-9.0 and alkalinity greater than acidity. Near-neutral $\mathrm{pH}$ could result from dissolution of limestone and other calcareous bedrock by the AMD or from mixing of acidic AMD with neutral, carbonate-buffered surface water (Broshears et al. 1996; Henry et al. 1999; Schemel et al. 2000). At near-neutral $\mathrm{pH}$, concentrations of dissolved $\mathrm{Al}^{3+}$ and $\mathrm{Fe}^{3+}$ are limited by the precipitation of hydrous oxide and hydroxysulfate minerals, and the transport of other toxic metals, such as $\mathrm{Cu}^{2+}, \mathrm{Pb}^{2+}, \mathrm{Ni}^{2+}$, and $\mathrm{Zn}^{2+}$, typically is attenuated owing to adsorption to such minerals (Bigham and Nordstrom 2000; Cravotta 2008; Webster et al. 1998; Winland et al. 1991). Nevertheless, even if concentrations of solutes in the water column are below toxicity thresholds, the accumulation of metal-rich solids within the streambed can degrade the benthic habitat and affect trophic structure and reproduction (Cannon and Kimmel 1992; Dsa et al. 2008; Havas and Rosseland 1995). Accordingly, strategies to treat the AMD before it discharges to streams commonly implement steps that increase $\mathrm{pH}$ and alkalinity, promote the oxidation of $\mathrm{Fe}^{2+}$ and $\mathrm{Mn}^{2+}$, and facilitate the precipitation and settling of hydrous oxides of $\mathrm{Fe}^{\mathrm{III}}, \mathrm{Mn}^{\text {III-IV }}$, $\mathrm{Al}$, and other metal-rich compounds (Johnson and Hallberg 2005; Ziemkiewicz et al. 2003).

Chemical conditions in streams may rebound quickly following neutralization of AMD; however, the recovery of aquatic invertebrates, zooplankton, and fish may take decades (Herricks 1977; Monteith et al. 2005; Vrba et al. 2003). Instead of continuous accrual of species over the improving chemical gradient, recovery tends to be punctuated, with groups of taxa added as particular chemical thresholds are attained (Monteith et al. 2005). Impediments to ecological recovery of acidified systems include inadequate or unstable water quality, residual effects of degraded substrate or habitat, inadequate or inaccessible supply of organisms for recolonization, and community-level competition and dynamics (Herricks 1977; Nelson and Roline 1996; Short et al. 1990; Yan et al. 2003).

Despite historical degradation from AMD, reproducing populations of brook trout (Salvelinus fontinalis) and other native fishes recently have been documented in several streams in the Anthracite coalfield of eastern Pennsylvania (Cravotta 2005; Cravotta and Bilger 2001; Cravotta and Kirby 2004) that had been considered fishless prior to recent surveys. The recent appearance of fish coincides with improved water quality of the streams and associated AMD sources, characterized by near-neutral $\mathrm{pH}$, increased alkalinity, and decreased concentrations of acidity and dissolved metals (Raymond and Oh 2009; Wood 1996). Because of progressive improvement in water quality and the recovery of native fish populations described in this paper, the upper Swatara Creek was recently characterized by the US EPA (2007) as a "nonpoint-source success story."

This paper tests the hypothesis that AMD treatment has improved downstream water quality and promoted the return of fish and other aquatic life to the upper Swatara Creek and its major tributaries during the period 19962007. The paper evaluates a unique combination of data from annual surveys of fish populations, continuous records of stream flow, temperature, $\mathrm{pH}$, and other chemical data for stream segments downstream from AMD sources during the study period. A companion paper (Cravotta 2010) describes the hydrochemical characteristics of the AMD sources and evaluates the effectiveness of specific treatment systems within the upper Swatara Creek Basin during the study period.

\section{Description of Study Area}

Swatara Creek drains an area of $1,472 \mathrm{~km}^{2}$ in the Ridge and Valley physiographic province of eastern Pennsylvania, flowing $115 \mathrm{~km}$ from its headwaters in the Southern Anthracite coalfield of Schuylkill County to its mouth on the Susquehanna River at Middletown, Dauphin County (Berg et al. 1989). Approximately $75 \%$ of the $112 \mathrm{~km}^{2}$ area of the upper Swatara Creek Basin, upstream from the US Geological Survey (USGS) stream flow-gaging station at Ravine (Fig. 1, \#01571820), is underlain by anthracite-bearing bedrock. During the late 1800s through the 1940s, extensive underground mines were developed to depths as great as 1,000 m (Eggleston et al. 1999; Wood et al. 1986). Current land use in the upper $112 \mathrm{~km}^{2}$ area is classified as $86.6 \%$ forested, $4.9 \%$ agricultural, and $6.4 \%$ "barren, mined." 
Fig. 1 Municipalities, "acidic" mine drainage (AMD), AMD treatments implemented during 1995-2001 with year of implementation in parentheses, and USGS monitoring stations in the Swatara Creek Basin upstream from the proposed dam for Swatara State Park Reservoir, Lebanon and Schuylkill Counties, Pennsylvania. USGS monitoring station numbers are indicated for sites with fish data

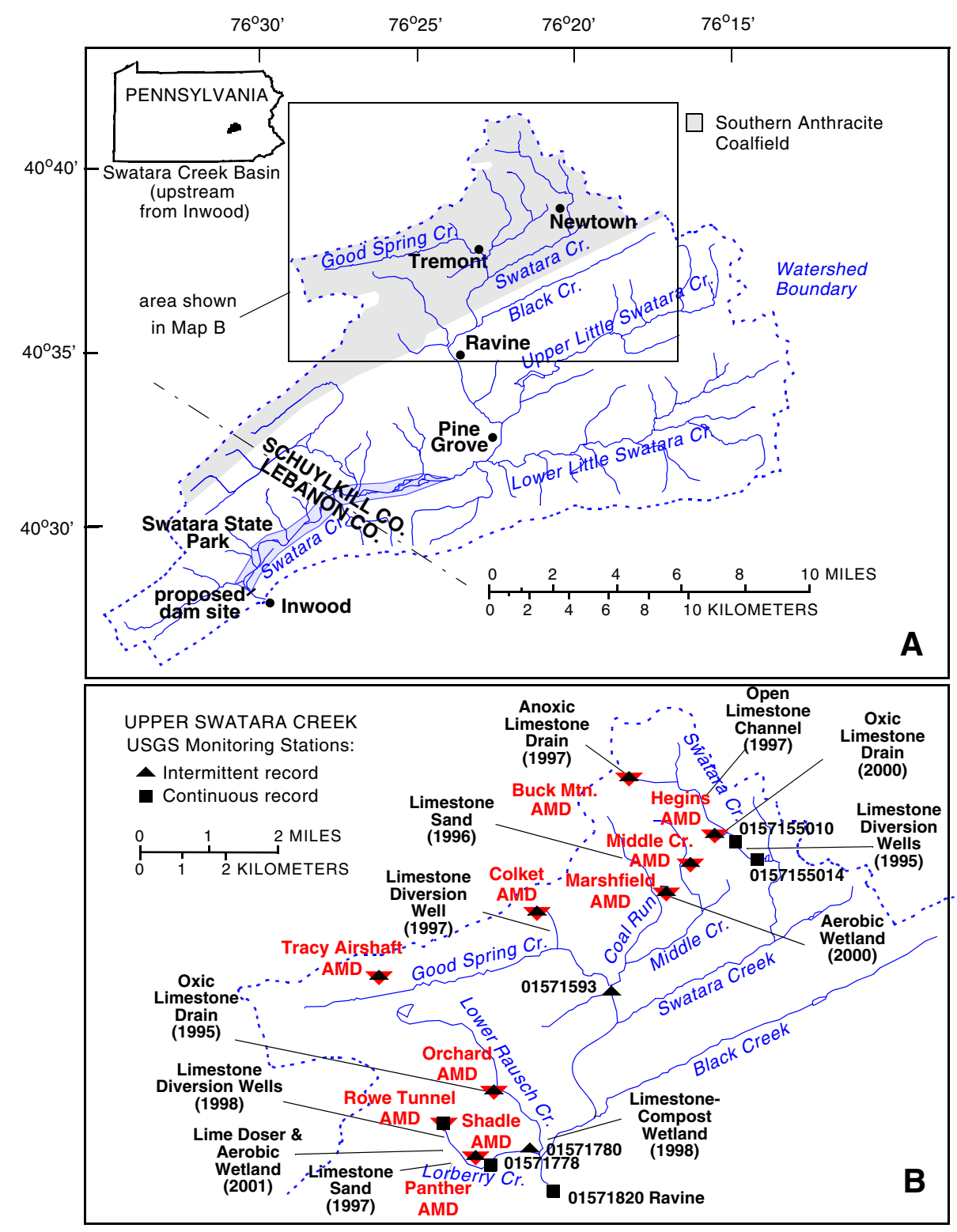

Prior to recent restoration efforts in the Swatara Creek Basin, surface water could drain to numerous abandoned underground mines through mine openings and subsidence pits. Further downstream, contaminated groundwater discharged from more than 40 AMD sources, degrading Swatara Creek and rendering the uppermost $20 \mathrm{~km}$ fishless for most of the twentieth century (Jackson 1987; Shoemaker 1932). Because of low $\mathrm{pH}$ and metals contamination from the AMD, Pennsylvania included upper Swatara Creek on the state's 303(d) list of impaired waters in 1996 and designated the upper basin a "high priority watershed" for reducing NPS pollution (Pennsylvania Dept of Environmental Protection 2007).

Various low-cost methods of treatment were implemented at or near the largest AMD sources, including open limestone channels, anoxic and oxic limestone drains, limestone diversion wells, hydrated lime dosing, and aerobic wetlands (Fig. 1b). Specific details on most of the AMD treatments, installed during 1995-2001, and their water-quality effects are reported by Cravotta (2010). Additionally, surface reclamation of abandoned mine land (AML) areas ranging from 7.7 to 35 ha over a total area of 230 ha or $2.3 \mathrm{~km}^{2}$ was implemented during this period (Pennsylvania Dept of Environmental Protection 2004).

\section{Methods of Data Collection and Analysis}

To provide detailed information at a range of scales, the USGS collected hydrologic data at more than 80 locations in the upper Swatara Creek Basin during 1996-2007 (USGS, variously dated). For this paper, a subset of the 
monitoring data collected at primary stream flow-gaging stations on Swatara Creek, Good Spring Creek, and Lorberry Creek were used (Fig. 1b).

Fish were collected annually in Swatara Creek at Ravine and Newtown, Good Spring Creek at Tremont, and Lorberry Creek near Ravine (Fig. 1b) by electrofishing over a $150 \mathrm{~m}$ reach consisting of mixed riffle, run, and pool habitats (Barbour et al. 1999). Stream habitat characteristics were recorded for each site, and individual fish were identified and measured before releasing most specimens.

To evaluate the cumulative effects of AMD remediation and the transport of pollutants from the mined part of the upper Swatara Creek Basin to unmined areas downstream, in 1996, the USGS reestablished 'continuous-record' stations for stream flow and water-quality monitoring on Swatara Creek at Ravine (\#01571820; 1996-2007) near the outlet of the $112 \mathrm{~km}^{2}$ upper basin, on Swatara Creek at Newtown (C3, \#0157155014; 1996-2007) near the headwaters, and on Swatara Creek at Pine Grove (\#01572025; 1996-2000) approximately $6 \mathrm{~km}$ downstream from the mined area (Fig. 1b). These sites had been monitored previously by USGS and others (Fishel 1988; Growitz et al. 1985; McCarren et al. 1964; Stuart et al. 1967). Additionally, continuous-record stream flow and water-quality gaging stations were established on Swatara Creek at Newtown (C1, \#0157155010; 1996-2007), upstream of limestone diversion wells, and on Lorberry Creek at Mollystown (\#01571778; 1999-2007) (Fig. 1b).

The continuous-record stations were equipped with automatic stage-recording, water-quality monitoring, and/or water-sampling devices. The stream stage was measured continuously with a pressure transducer, and the temperature, $\mathrm{pH}$, and specific conductance (SC) were measured continuously with a multi-parameter sonde. The stage and water-quality values were recorded at $15 \mathrm{~min}$ intervals. To estimate continuous stream flow, stage-discharge ratings were developed for each site on the basis of instantaneous stream flow for a range of stream stages. Stream flow typically was measured by wading across the channel with a vertical-axis current meter.

Instantaneous data for temperature, $\mathrm{SC}, \mathrm{pH}$, redox potential (Eh), and dissolved oxygen (DO) were measured using standard field methods when continuous-record data were retrieved at stream flow-gaging stations or when water-quality samples were collected. Fixed-interval grab samples, mostly at base-flow conditions, were collected at 4- or 6-week intervals from well-mixed zones in the stream. For Swatara Creek at Ravine (\#01571820), Swatara Creek at Newtown (\#0157155014), and Lorberry Creek at Mollystown (\#01571778), numerous additional base-flow and storm flow samples were collected using pumping samplers containing 24-1 L polyethylene bottles. Storm flow samples submitted for analysis were selected to cover rising, peak, and falling stages of the hydrograph. Storm flow samples of Swatara Creek at Ravine were analyzed for more than 60 events during the study. Bulk precipitation samples were also collected and analyzed for a few of the storms.

Whole-water samples were analyzed in the laboratory within $24 \mathrm{~h}$ of collection for $\mathrm{pH}$ and alkalinity to a $\mathrm{pH} 4.5$ endpoint (American Public Health Association 1998a). Samples for 'dissolved' (filtered through a $0.45 \mu \mathrm{m}$ pore size membrane) and total (whole-water; in-bottle digestion with nitric acid $\left(\mathrm{HNO}_{3}\right)$ and hydrochloric acid $(\mathrm{HCl})$ ) metal analysis were stored in acid-rinsed polyethylene bottles and acidified with $\mathrm{HNO}_{3}$. The water samples were analyzed for major ions and trace metals by inductively coupled plasma atomic emission spectrometry (ICP-AES), ion chromatography (IC), colorimetry, and electrometric titration at the Pennsylvania Department of Environmental Protection (PaDEP) Bureau of Laboratories facility in Harrisburg, PA, during 1996-2000, at the US Department of Energy (USDOE) laboratory in Pittsburgh, PA, during 2001-2002, and at the Actlabs laboratory in Toronto, Ontario, during 20032007. Although similar analytical procedures were used, the laboratories reported different limits of detection for aluminum and trace metals. Data for environmental waterquality and quality-assurance samples collected during the study were stored in the USGS National Water Information System (NWIS) database (http://waterdata.usgs.gov/pa/ nwis/qw).

Hardness was computed from the concentrations of dissolved calcium and magnesium in $\mathrm{mg} / \mathrm{L}$ as $\mathrm{CaCO}_{3}(2.5$ $\mathrm{C}_{\mathrm{Ca}}+4.1 \mathrm{C}_{\mathrm{Mg}}$ ). The net acidity, which is similar in value to the 'hot peroxide' acidity (American Public Health Association 1998b), was computed considering positive acidity contributions from protons and concentrations of dissolved iron, manganese, and aluminum, and negative contributions from alkalinity as described by Kirby and Cravotta (2005). Because the hot acidity values obtained for this study did not include negative values, only the net acidity is evaluated in this paper.

To compare hydrologic conditions among sites during the study with the long-term record, stream flow duration records (probability plots) for the Ravine and Newtown stream flow-gaging stations were displayed with records for stations on Swatara Creek at Pine Grove (\#01572025) and Harper Tavern (\#01573000), which were 7.7 and $48.0 \mathrm{~km}$ downstream from Ravine, respectively. Daily mean stream flow values for these sites also were used with the PART hydrograph-analysis computer program (Rutledge 1998) to estimate annual mean stream flow and baseflow and surface-runoff contributions during the study. Interbasin variability during the study was indicated by the stream flow 'yield', computed by dividing the annual stream flow by the estimated drainage area at the gaging station. 
A multivariate approach was used to estimate chemical concentrations and annual loads and corresponding trends in these parameters for the 1997-2006 period for Swatara Creek at Ravine (\#01571820) and Swatara Creek at Newtown (\#0157155010 and \#0157155014). This approach, described by Langland et al. (2006), uses the log-linear 7-parameter ESTIMATOR regression model of Cohn et al. (1989) with daily mean stream flow and time parameters to estimate the continuous distribution of daily concentration values. The daily concentration estimates are multiplied by daily mean stream flow and integrated over time to indicate annual loads. By dividing the annual load by the annual stream flow, the annual mean flow-weighted concentration was computed for each year of the study. The flowweighted concentration computed on this basis is considered an unbiased estimate of the mean concentration (Langland et al. 2006).

In accordance with Langland et al. (2006), flow-adjusted trends were estimated considering the time terms in the log-linear regression model. The flow-adjusted trends, expressed as percent difference, indicate the overall change between the start date (1997) and the end date (2006) of the study and are mathematically identical for concentration and load. Changes were considered significant only if the confidence interval of the modeled value at the end of 2006 was entirely greater than (upward trend) or entirely less than (downward trend) the modeled starting value. The results of flow-adjusted trend analysis can be interpreted to indicate changes in water quality that result from factors other than stream flow, such as changes in land use or other management practice (Helsel and Hirsch 2002).

\section{Results}

Return of Fish Populations, 1996-2006

During the 1990s, native fish populations returned to upper Swatara Creek. No fish were found during ecological surveys of Swatara Creek at Ravine prior to 1990 (Jackson 1987; Shoemaker 1932). Yet, in 1996, six species of fish, including blacknose dace (Rhinichthys atratulus), brook trout (Salvelinus fontinalis), and white sucker (Catostomus commersoni) were captured by electrofishing (Table 1). The colonizing fish are assumed to have originated from wild stocks in unaffected or marginally affected tributaries and downstream reaches in the watershed. From 1996 to 2002, the number of fish species in Swatara Creek at Ravine increased annually to 25 species (Table 1; Fig. 2). However, during high base-flow conditions in 2003 and 2004, fewer fish were captured than preceding years
(Fig. 2). When the surveys were resumed in 2005 and 2006, base-flow conditions were comparable to earlier survey conditions and large numbers of fish of various species were captured.

The number of fish species and total number of fish counted during annual surveys were negatively correlated with the minimum stream flow during the week of the survey (Spearman's rho $=-0.70$ and -0.89 , respectively) (Fig. 2a, b) and positively correlated with the maximum pH (Spearman's rho $=0.60$ and 0.81) and SC (Spearman's rho $=0.84$ and 0.90 ) during the week of the survey. Although not correlated with the water temperature during the survey, the abundance of brook trout, a cold-water species, was negatively correlated with the maximum daily temperature during summer months preceding the survey (Fig. 2c). The water temperature during summer months, $\mathrm{pH}$, and SC generally decreased with increased stream flow. Furthermore, higher flow conditions on the date of the survey increased water depth, turbidity, and velocity of transport of stunned fish resulting in reduced capture efficiency. Fish species that were counted at a high frequency during the higher stream flow conditions, notably rock bass (Ambloplites rupestris), were concentrated near large rocks and boulders along the stream bank and were more easily captured than other fish species at higher flows.

In 1996 and 2006, stream flow conditions of Swatara Creek at Ravine during the dates and weeks of fish surveys were similar (Fig. 2). Despite similar survey conditions and methods, only 76 fish of 6 species were collected in 1996 compared to a total of 195 fish of 16 species in 2006. A fraction of the fish species identified at Ravine was found at upstream sites on Good Spring Creek at Tremont, Lorberry Creek at Lorberry Junction, and Swatara Creek at Newtown during the study (Table 1). Comparing survey results for 1996 and 2006, increases in fish-species diversity were also apparent for Good Spring Creek at Tremont (5 species in 1996; 9 species in 2006) and Swatara Creek at Newtown (0 fish in 1996; 2 brook trout in 2006) (Fig. 2). Although stream flow and water quality were variable, the aquatic habitat conditions in Swatara Creek at Ravine and upstream sites of fish surveys were unchanged during 1996-2006.

As indicated by box plots summarizing water-quality data for the sites where fish surveys were conducted, Swatara Creek at Ravine and Good Spring Creek at Tremont generally exhibited net-alkaline water quality with consistently near-neutral pH during the study (Fig. 3); these two sites also had the largest stream flow and yielded the greatest numbers of fish compared to Lorberry Creek and Swatara Creek at Newtown (Fig. 2). In contrast, the water quality for Lorberry Creek and Swatara Creek at Newtown frequently was acidic, with corresponding values of $\mathrm{pH}$ ranging to 5.5 and less during the study (Fig. 3). 


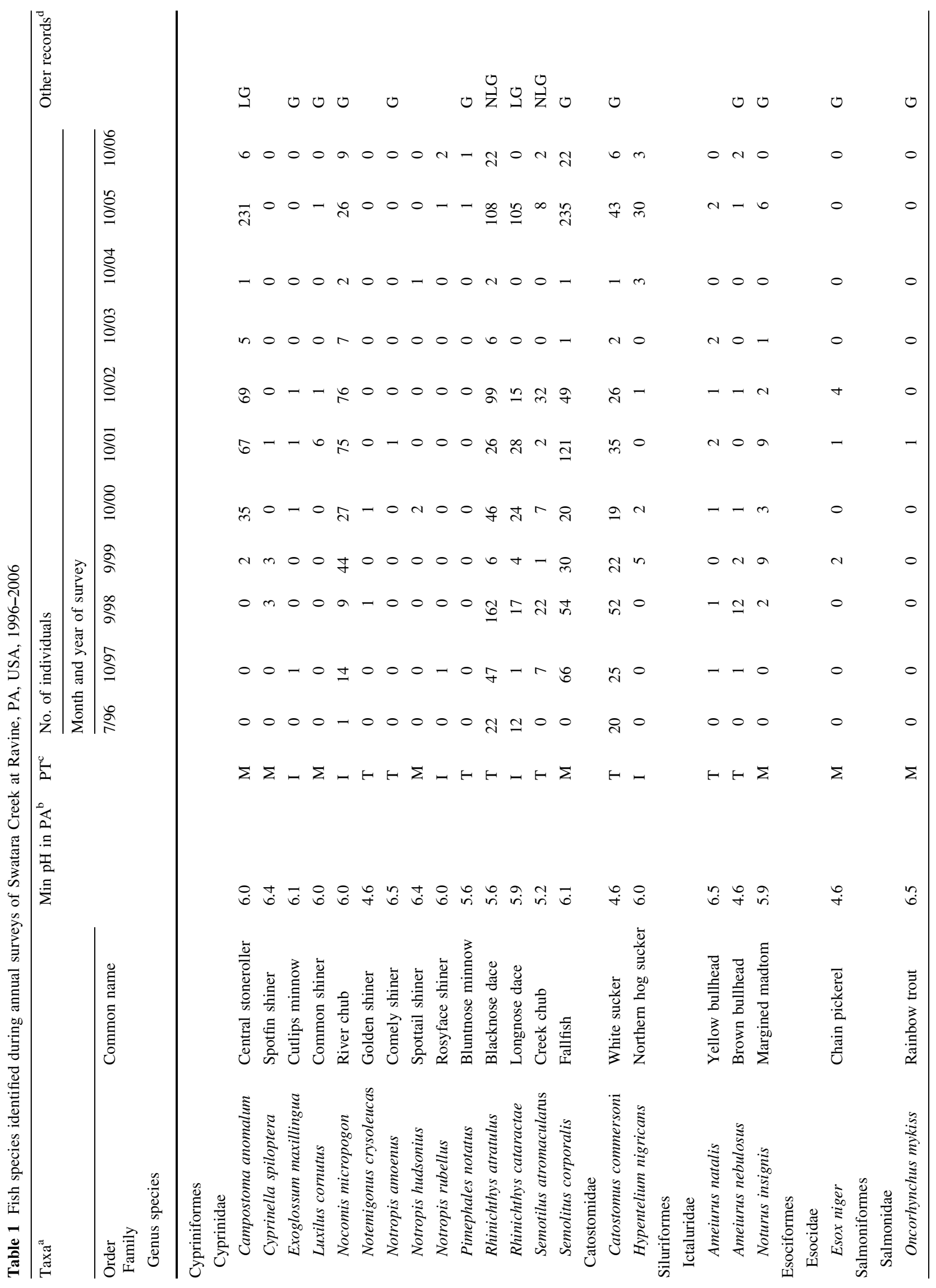




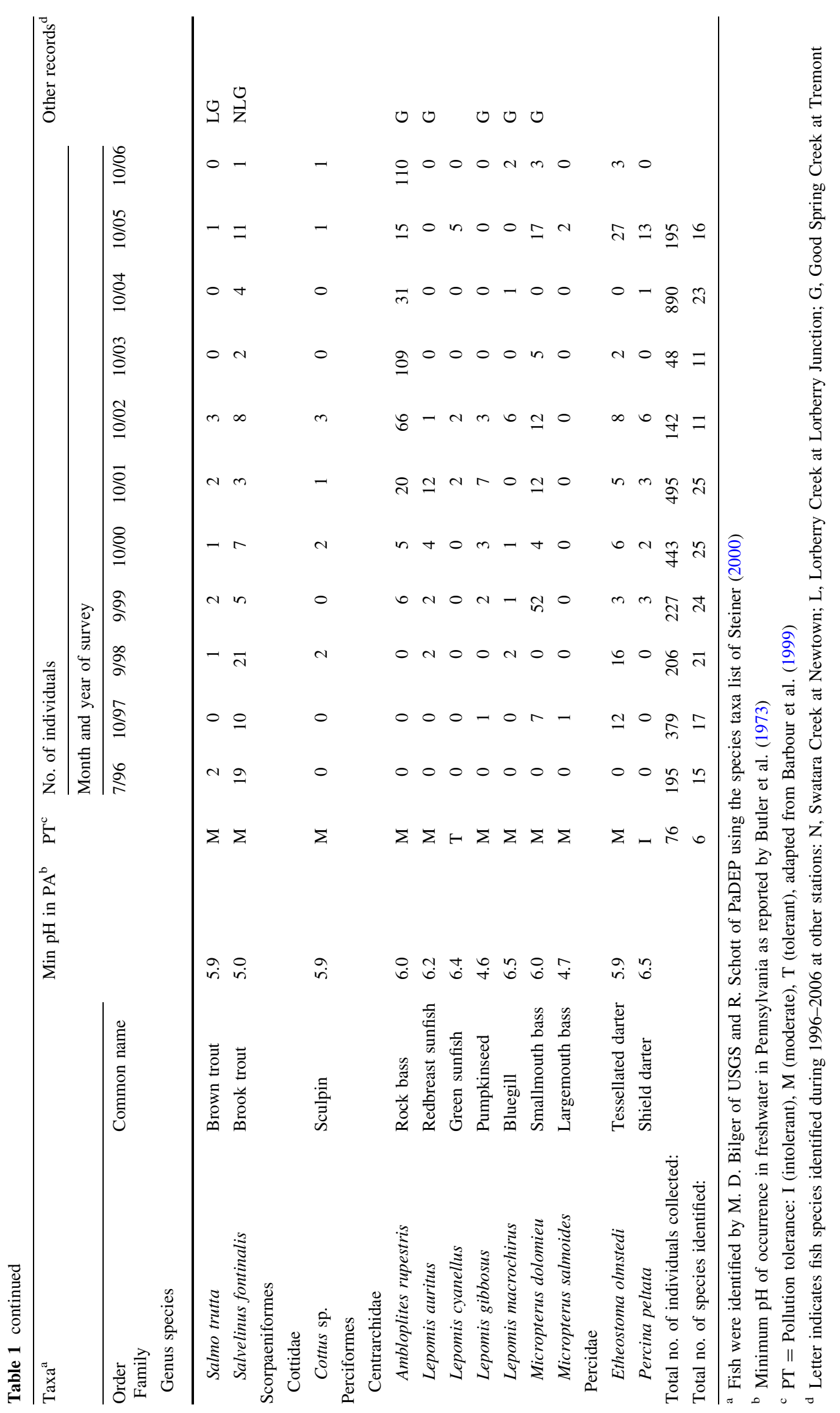


Fig. 2 Annual electrofishing survey results at selected sites* in Swatara Creek Basin, 19962006: a total number of fish at each site; $\mathbf{b}$ number of fish species at each site; c percentage of brook trout relative to total number of fish at Swatara Creek at Ravine. *Lorberry Creek was not surveyed before 2002. In a and b, solid black line indicates observed streamflow for Swatara Creek at Ravine during survey; vertical error bars indicate range of daily mean streamflow at Ravine during the week before the survey. In c, solid black line indicates daily mean temperature in July and August; vertical error bars indicate associated range of daily mean temperature; dashed horizontal line indicates maximum temperature permitted for "cold-water fishery" in July and August (Commonwealth of Pennsylvania 2002)
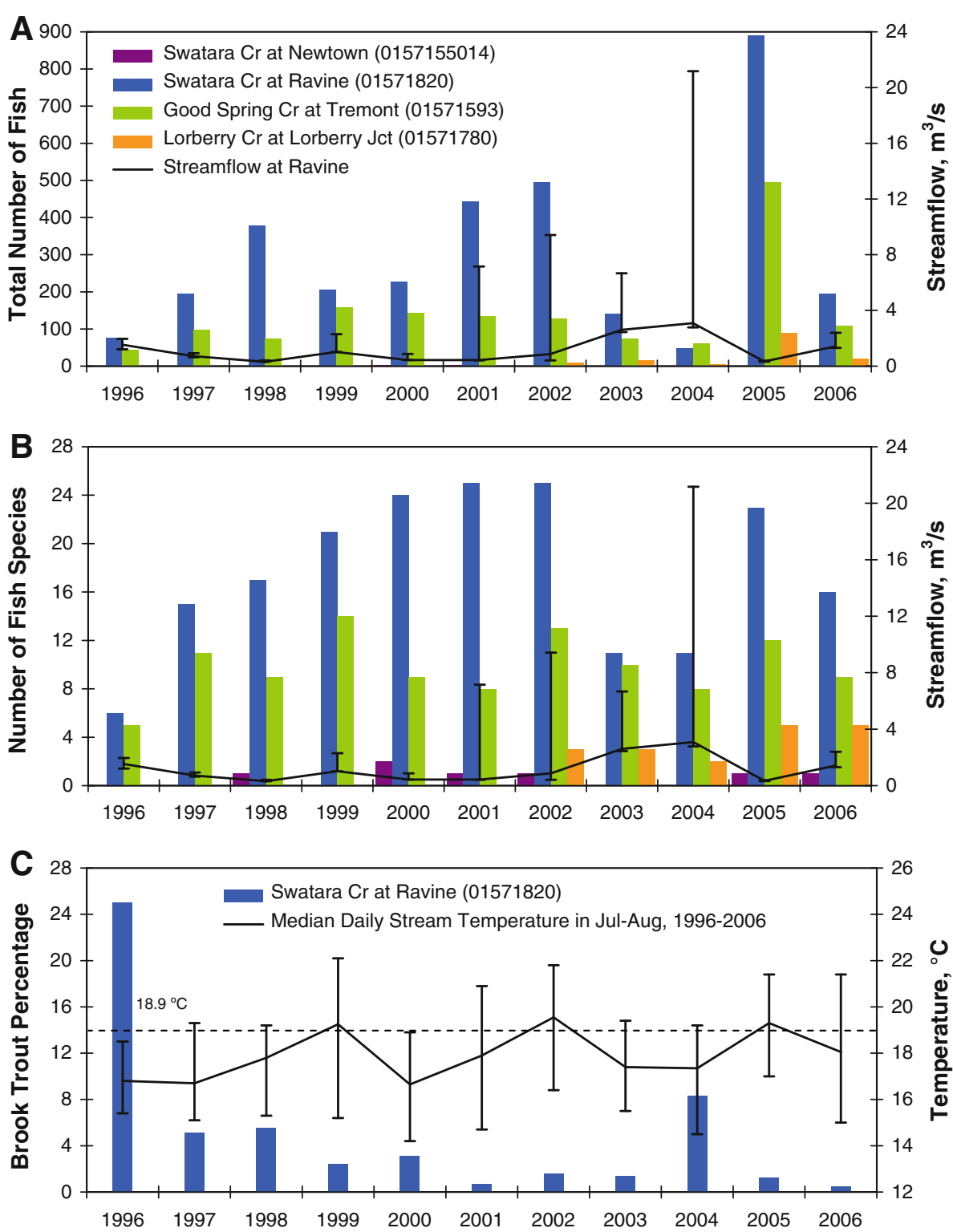

Streamwater Quality and Stream flow

Temporal variability in stream flow is one of the most important factors affecting water quality. Although annual stream flow was within the normal range during 1996-1998 and 2005-2007, it was lower than normal in 1999-2001 and greater than normal in 2002-2004 (Figs. 4a, 5a). Hydrograph separation with PART (Rutledge 1998) indicated the total stream flow at Ravine during the study was composed of about $75 \%$ base flow and $25 \%$ storm runoff. Generally the runoff associated with storm flow events lasted from hours to several days.

Expressed as the yield, where stream flow is divided by drainage area, the upstream station on Swatara Creek at Newtown had lower annual mean stream flow $(54.0 \mathrm{~cm} /$ year) than downstream gaging stations on Swatara Creek at
Ravine (69.5 cm/year), Pine Grove $(65.1 \mathrm{~cm} /$ year), and Harper Tavern $(63.4 \mathrm{~cm} /$ year $)$. Relatively small stream flow yields for Swatara Creek at Newtown are consistent with this drainage area losing water to the underground mine that flows eastward to the Otto Colliery in the adjacent watershed (Gannett Fleming Corddry and Carpenter, Inc. 1972). In contrast, large stream flow and base-flow yields for Lorberry Creek (109 and $84.7 \mathrm{~cm} /$ year, respectively) are consistent with groundwater inflows from outside the delineated watershed. The Rowe Tunnel drains the Lincoln Mine pool that extends beneath the Lorberry Creek and Lower Rausch Creek watersheds.

At Ravine, the continuously recorded $\mathrm{pH}$ ranged from 4.7 to 8.2 and SC ranged from 27 to $540 \mu \mathrm{S} / \mathrm{cm}$ during the study (Figs. 4, 6); pH and SC values generally decreased with increased stream flow (Fig. 6). Minimum values of $\mathrm{pH}$ 

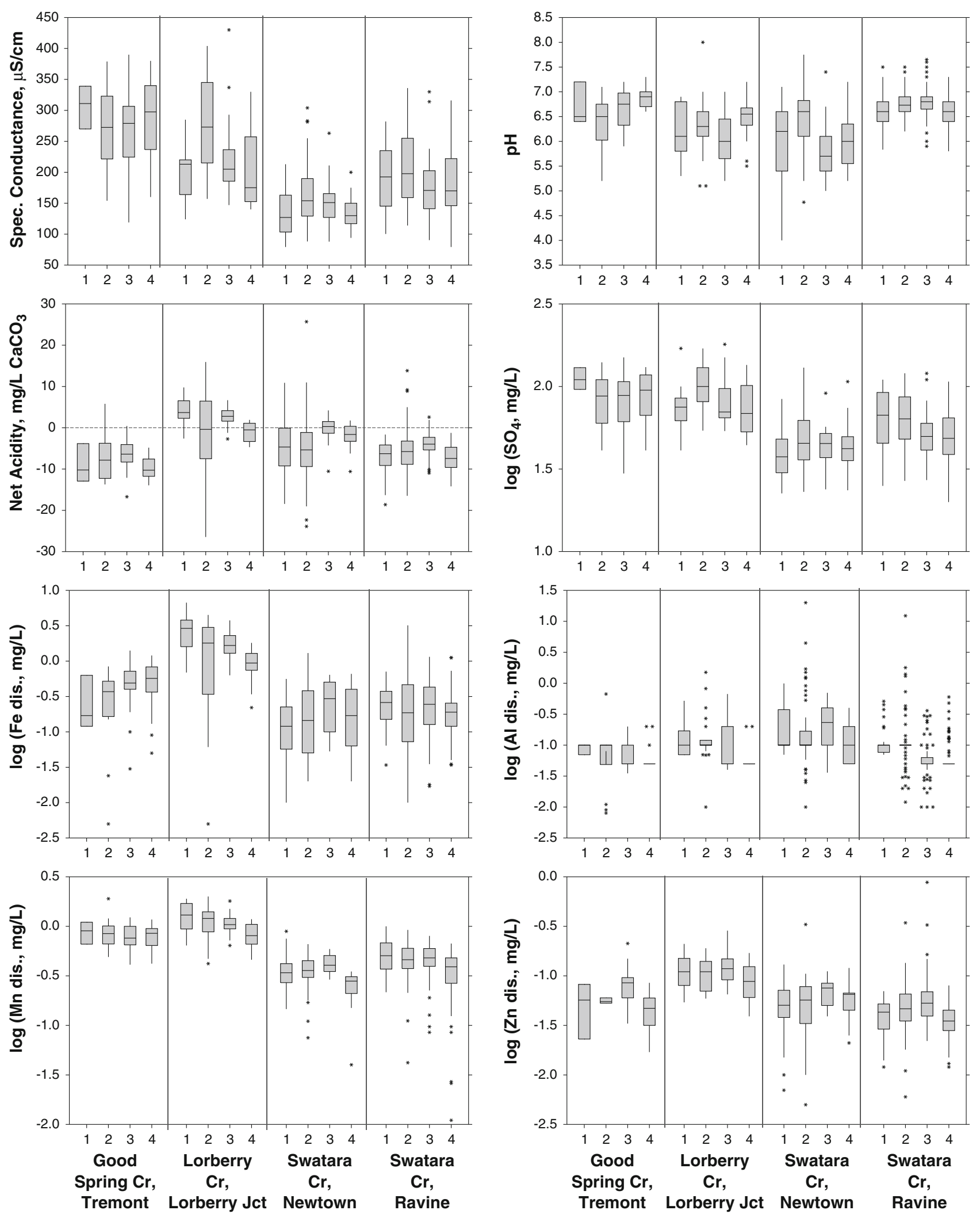

Fig. 3 Boxplots summarizing hydrochemical characteristics of stream water at sites of annual fish surveys in Swatara Creek Basin, PA, over 3year intervals: (1) 1996-1998, (2) 1999-2001, (3) 2002-2004, (4) 2005-2007. Shaded area of box indicates the "interquartile" range

$(\mathrm{IQR}=25$ th to 75 th percentile $)$; horizontal line inside the box indicates the median; vertical lines extend to extreme values within 1.5 times the IQR; symbols indicate outlier values 
Fig. 4 Probability plots of continuously measured (recorded at 15-min intervals) data for Swatara Creek at Ravine, PA, September 1996 through September 2007: a, streamflow; b, pH; c, specific conductance; $\mathbf{d}$, temperature.

The $x$-axis indicates the frequency that values were exceeded during 3-year intervals
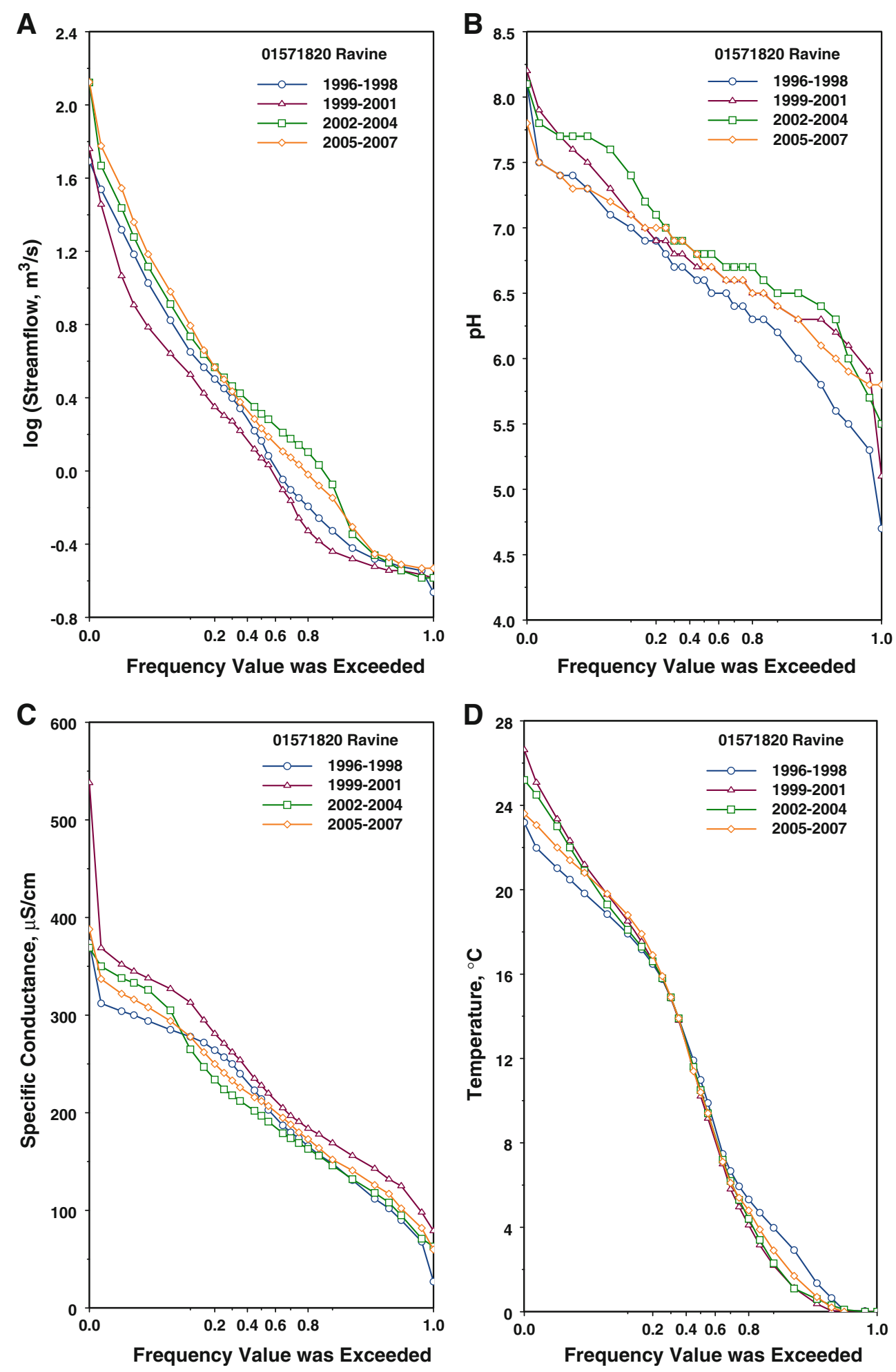

and SC were recorded for storm flow, implying that storm runoff that mixes with base flow is both acidic and dilute, as explained in more detail below.

One could hypothesize that with the implementation of limestone-based treatment systems at many of the AMD sources in the Swatara Creek Basin during the late 1990s
(Fig. 1b), stream flow would not be affected, but pH, alkalinity, and calcium concentrations would increase at downstream sites. Frequency distribution plots of continuous-record stream flow, $\mathrm{pH}, \mathrm{SC}$, and temperature of Swatara Creek at Ravine for 3-year intervals during 19962007 (Fig. 4) show that the stream flow distribution during 
Fig. 5 Time-series plots of the monthly range (maximum and minimum) of daily mean values for Swatara Creek at Ravine, PA, June 1996 through June 2007: a, streamflow; b, pH; and c, temperature. In $\mathbf{b}$ and $\mathbf{c}$, dashed horizontal lines indicate minimum $\mathrm{pH}$ and maximum temperature permitted for "cold-water fishery" in July and August, respectively (Commonwealth of Pennsylvania 2002)
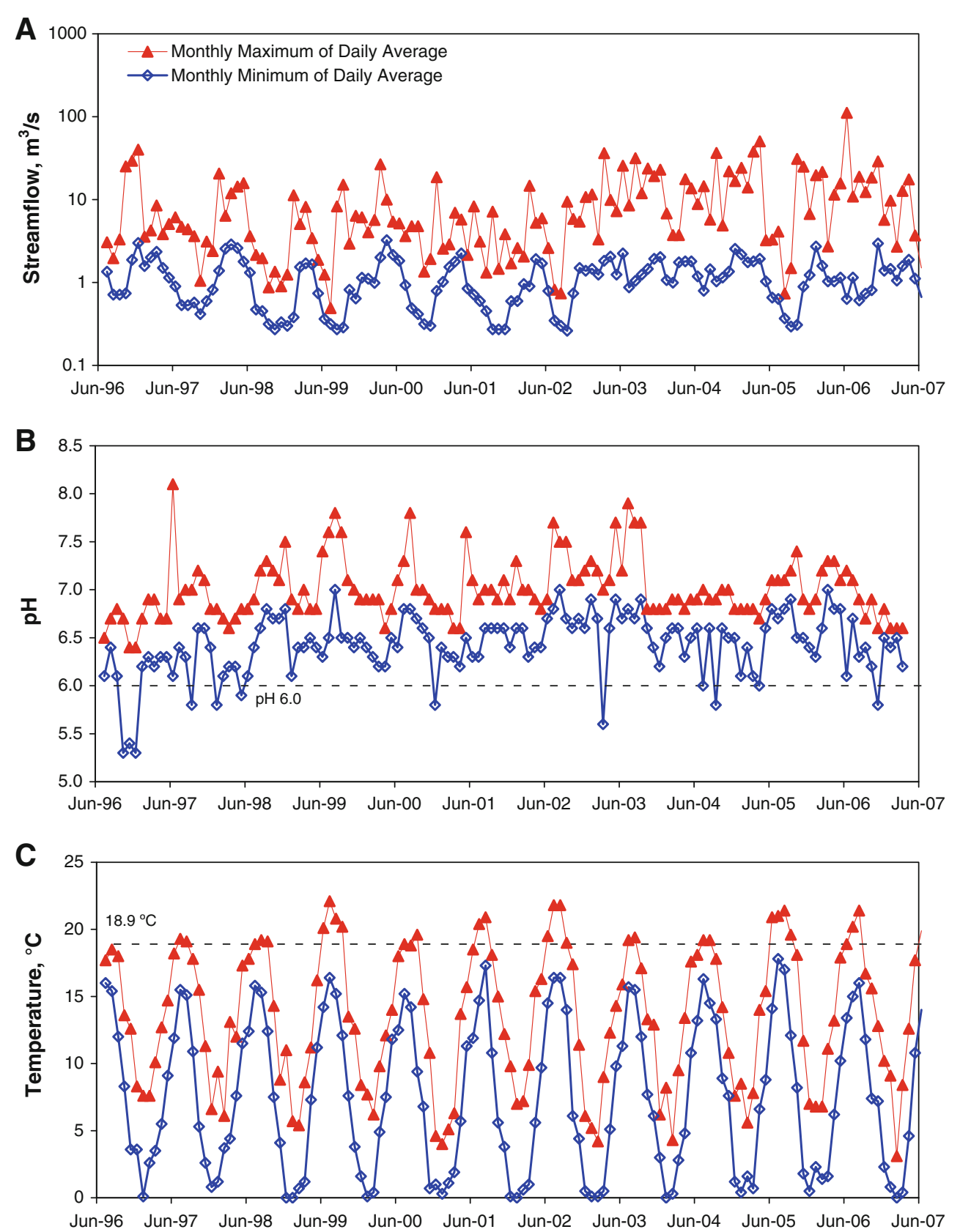

1996-1998 was comparable to the long-term distribution. However, during the 1996-1998 period, Swatara Creek had a greater frequency of low values of $\mathrm{pH}$ and $\mathrm{SC}$ and a smaller range in temperature compared to later periods (Figs. 4, 5). The decrease in the frequency of low values of $\mathrm{pH}$ and $\mathrm{SC}$ and the increase in the range of temperature after 1998 coincide with, and could result from, the implementation of AMD treatments. Limestone diversion wells, limestone drains, and limestone channels are sources of dissolved solids (as calcium and alkalinity) that would tend to increase the $\mathrm{pH}$ and SC. Constructed wetlands and the diversion of streams from mines to surface channels would have little effect on dissolved solute concentrations but could affect water temperature. After 1998, maximum stream temperatures increased during summer months and decreased during winter months (Fig. 5). This increased range in maximum temperature is consistent with increased thermal exchange with the ambient atmosphere that could result from the impoundment of AMD in wetlands and the restoration of stream flow at mine-infiltration sites. Evaporation of stream water during low-flow periods would tend to amplify these effects on temperature and SC.

During 1996-2007, stream-water-quality samples for chemical analysis were collected for a wide range of hydrologic conditions. The samples collected with automated sampling devices during storm events were identified 
A

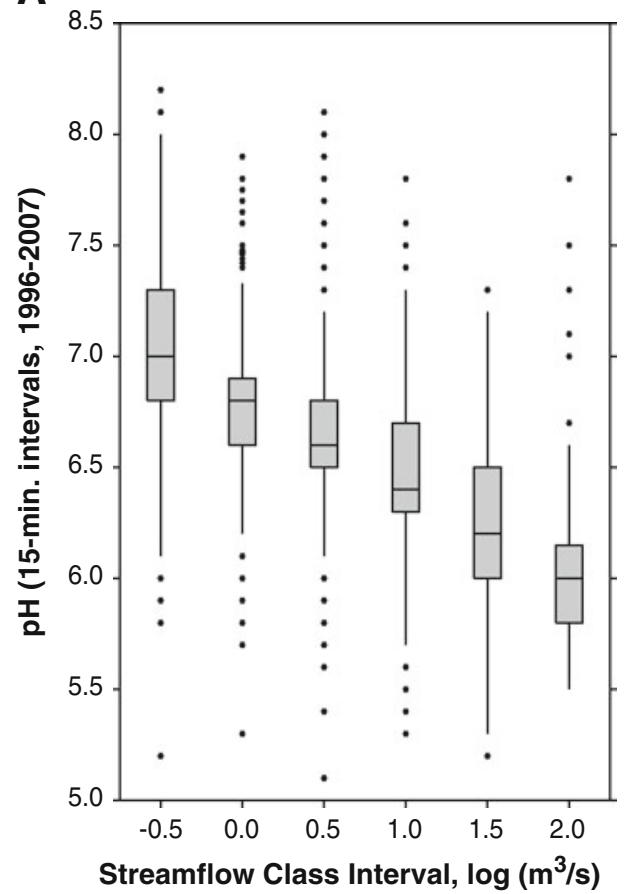

Fig. 6 Boxplots showing continuously measured (recorded at 15-min intervals) $\mathrm{pH}$ and specific conductance as a function of streamflow for Swatara Creek at Ravine, PA, September 1996 through September 2007. Each streamflow class interval on the $x$-axis, where numbers are logged values of streamflow in cubic meters per second, includes

as rising, peak, and falling 'storm flow' samples on the basis of the hydrograph for Swatara Creek at Ravine on the date of sampling. Samples collected during relatively stable stream stage between storm events were characterized as normal, low, and high 'base-flow' samples.

\section{Base Flow}

Current and historical data from 1959 to 2007 for Swatara Creek at Ravine indicate progressive improvement in stream water quality (Fig. 7). Although stream flow at times of collection of historical (1959-1985) and current (19962007) base-flow samples generally was comparable, sulfate decreased from a median of about $150 \mathrm{mg} / \mathrm{L}$ in 1959 to $75 \mathrm{mg} / \mathrm{L}$ in 2007; $\mathrm{pH}$ increased sharply from 3.5-4.4 (median $\approx 4)$ to $4.6-7.0$ (median $\approx 6.5$ ) after 1995 (Fig. 7). Concentrations of dissolved iron and aluminum generally decreased with increased $\mathrm{pH}$. The decrease in concentrations of sulfate and associated AMD contaminants in Swatara Creek prior to remedial work in 1995-2001 could have resulted from a progressive decrease in contaminant loading from AMD sources after the initial flooding of the abandoned mines. Flooding of a mine can result in the: (1) dissolution of accumulated pyrite-oxidation products, (2) reduction in the access of oxygen to the subsurface with a

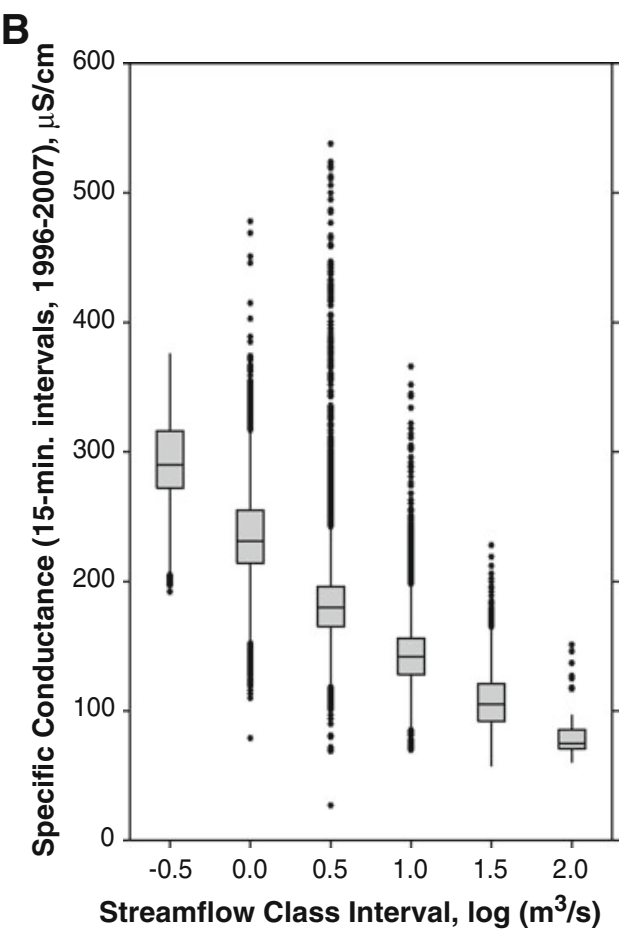

values within 0.25 of the listed value (e.g. 1.0 is $0.75-1.25$ ). Shaded area of box indicates the "interquartile" range (IQR $=25$ th to 75 th percentile); horizontal line inside the box indicates the median; vertical lines extend to extreme values within 1.5 times the IQR; symbols indicate outlier values

corresponding decrease in the pyrite oxidation rate, and (3) progressive dilution of initially acidic water by alkaline groundwater inflows. Such processes could account for gradual improvement in AMD and surface-water quality that has been ongoing for decades throughout the region, particularly in the Northern, Western, and Southern Anthracite coalfields (Wood 1996). The associated increase in $\mathrm{pH}$ of Swatara Creek probably was caused by the onset of carbonate buffering that occurred when the rate of alkalinity production equaled or exceeded acid production. The implementation of limestone-based treatment systems during 1995-2001 would be expected to enhance the potential for carbonate buffering.

\section{Storm Flow}

Storm-runoff events can occur year round in the study area and can have a dramatic effect on stream flow. Generally, monthly runoff as a fraction of total stream flow (estimated with PART, Rutledge 1998) was greatest during the late summer and early fall, when seasonal low base flow was punctuated by large storms of tropical origin. Months with an exceptionally high fraction of storm flow during the study included October 1996 (47\%), September 1999 (58\%), September 2001 (46\%), October 2003 (45\%), September 

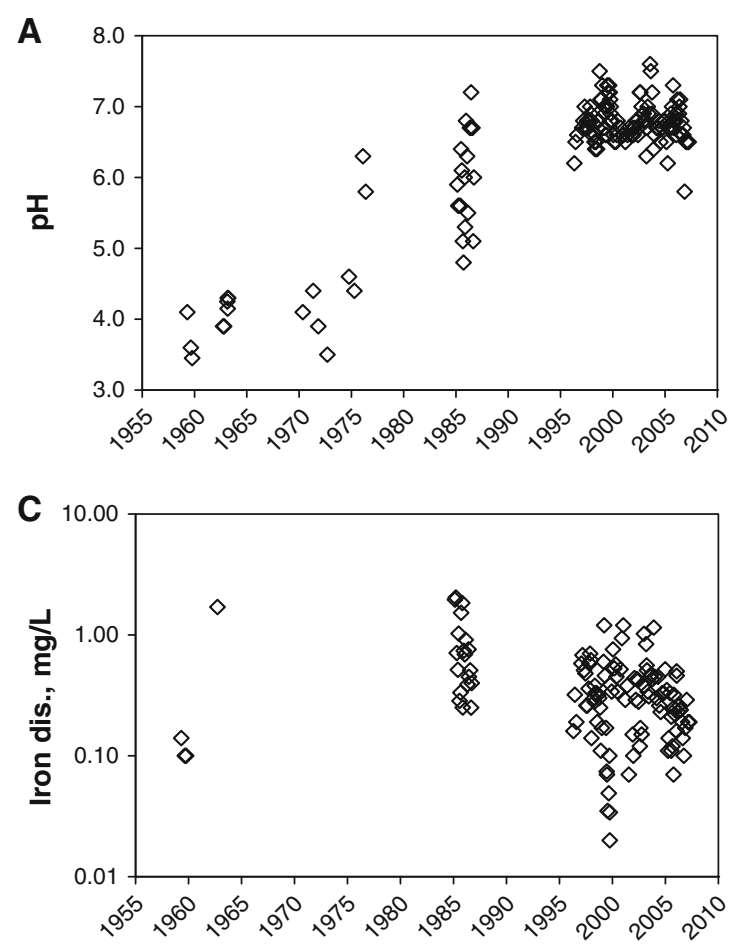

Fig. 7 Long-term water-quality data for base flow of Swatara Creek at Ravine, 1959-2007: a, pH; b, dissolved sulfate; c, dissolved iron; d, dissolved aluminum. Data from McCarren et al. (1964), Stuart et al.

2004 (70\%), and October 2005 (52\%). Several examples of storm hydrographs during September and October 19962006 with associated stream chemistry are illustrated in Fig. 8. The same vertical axes for stream flow, SC, and sulfate; $\mathrm{pH}$; and concentrations of suspended solids, total iron, and dissolved iron were used so that storm characteristics can be compared. Although each storm hydrograph is unique, owing to variations in storm duration, intensity, and runoff contribution, some features are consistent among the hydrographs. Specifically, as stream flow increased during storm events, the $\mathrm{pH}, \mathrm{SC}$, and sulfate concentration decreased, whereas the concentrations of suspended solids and total and dissolved iron increased (Fig. 8). Other sampled hydrographs for all months of the year exhibited comparable patterns, except that storm events during 19961998 exhibited greater propensity for change in $\mathrm{pH}$, with lower extremes (Fig. 4b) than later years.

Six bulk precipitation samples were collected during June 1999-June 2000 at Ravine or Pine Grove. The rain had the following median and range values: $\mathrm{pH}=4.7$ (4.1-6.2), $\mathrm{SC}=18 \mu \mathrm{S} / \mathrm{cm}(6-78 \mu \mathrm{S} / \mathrm{cm})$, sulfate $=2.4 \mathrm{mg} / \mathrm{L}(<1-$ $5.9 \mathrm{mg} / \mathrm{L})$, and total iron $=0.053 \mathrm{mg} / \mathrm{L}(0.043-0.077 \mathrm{mg} /$ L). Only one rain sample had $\mathrm{pH}>5$; the high $\mathrm{pH}$ value for this sample may represent the influence of dust or other debris.
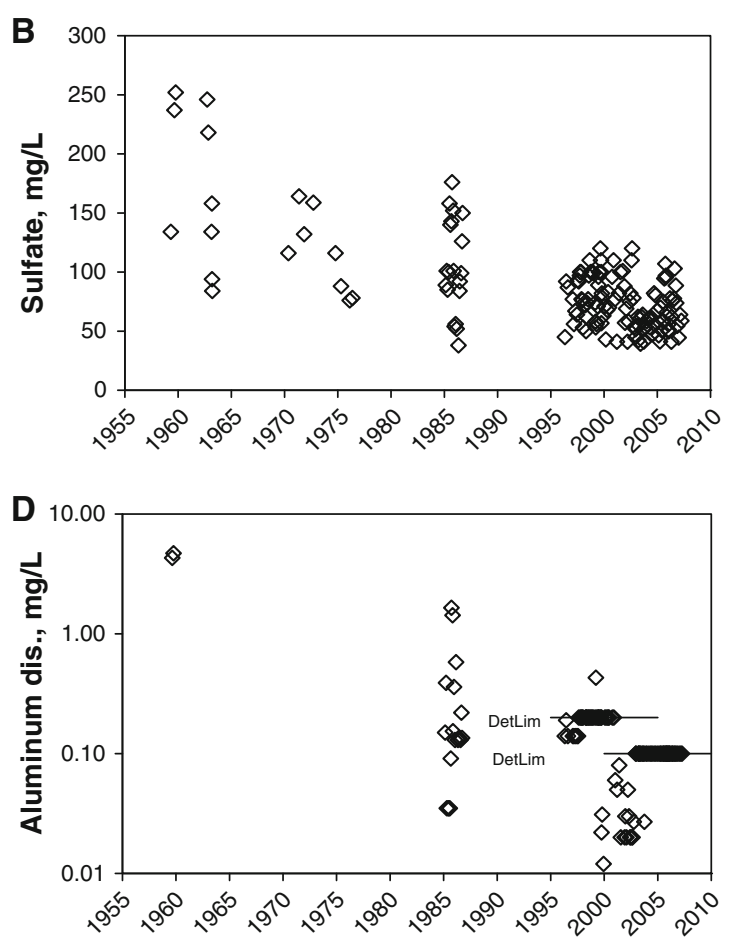

(1967), Fishel (1988), and US Geological Survey (variously dated). Aluminum concentrations below detection are shown at detection limit (DetLim), indicated by horizontal line segments

\section{Discussion}

Correlations among Stream Flow, Metals, and Suspended Solids

The $\mathrm{pH}, \mathrm{SC}$, sulfate, and other chemical concentrations varied in response to changes in stream flow. Generally, base-flow samples had higher $\mathrm{pH}, \mathrm{SC}$, alkalinity, hardness, and concentrations of dissolved major ions and lower concentrations of total metals compared to storm flow (Figs. 8, 9).

As stream flow at Ravine increased during storm flow events, $\mathrm{pH}, \mathrm{SC}$, and concentrations of sulfate and manganese typically decreased, and concentrations of suspended solids, iron, aluminum, and other metals in whole-water samples typically increased (Figs. 8, 9). Similar trends for dissolved and suspended solids during storm flow on Swatara Creek in 1959 were reported by Stuart et al. (1967, Fig. 8). However, the trends for $\mathrm{pH}, \mathrm{SC}$, and sulfate are inconsistent with the work of others who evaluated impacts of acid rain on small streams in unmined, forested watersheds of the Appalachian Mountains of northeastern USA. For example, Corbett and Lynch (1982) showed pH typically decreased while sulfate increased with stream flow in Appalachian headwater streams during storm events. 

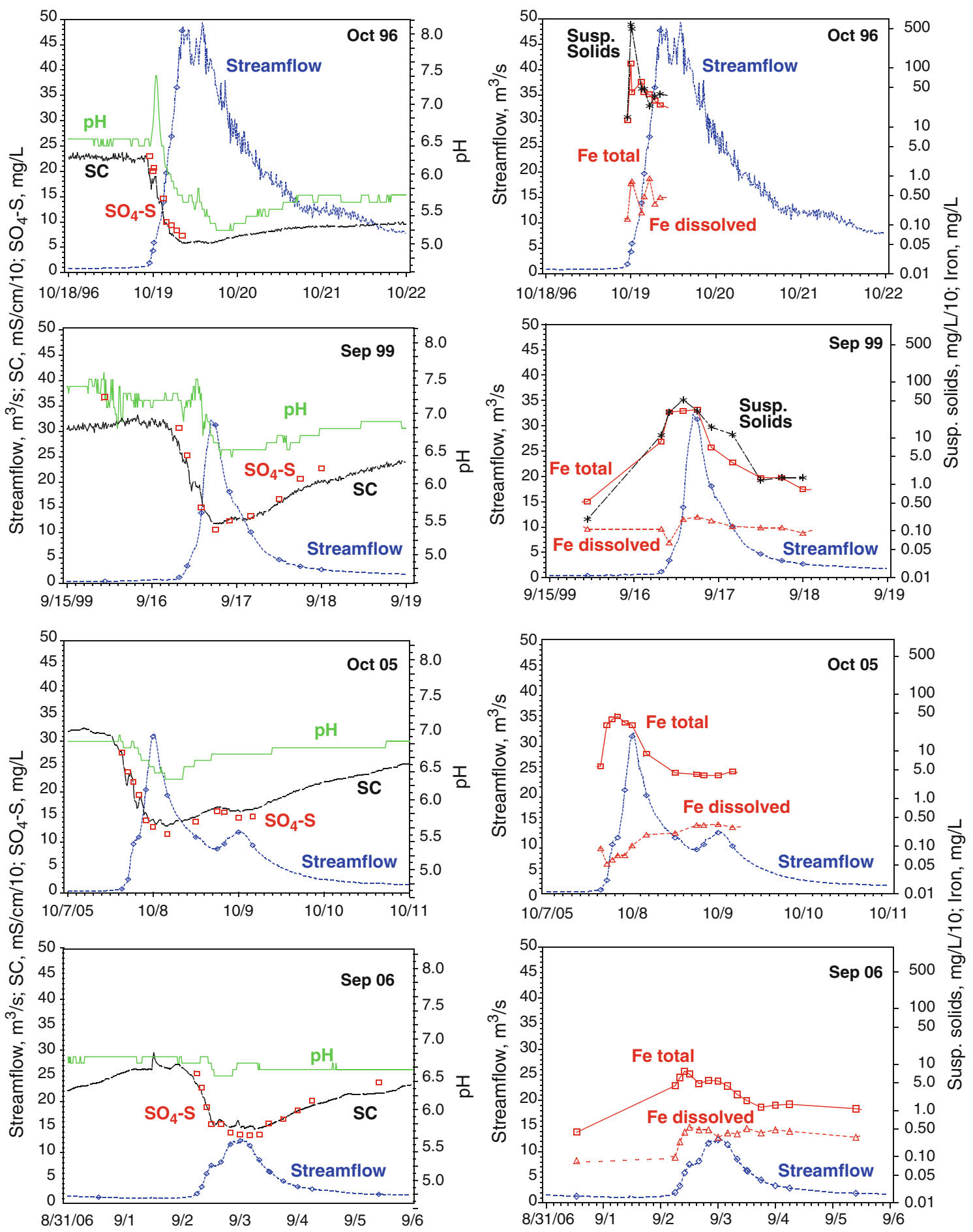

Fig. 8 Hydrographs and associated water-quality data for selected stormflow events, Swatara Creek at Ravine, PA. October 19-21, 1996; September 16-17, 1999; October 7-9, 2005; and September

2-4, 2006. Values shown for SC and suspended solids (divided by 10) and concentration of $\mathrm{SO}_{4}$ (divided by 3 ) as sulfur

Cravotta (2000) demonstrated that the decreases in $\mathrm{pH}$, $\mathrm{SC}$, and concentrations of major ions during storm events for Swatara Creek could result from mixing of weakly acidic storm runoff having $\mathrm{pH} 4.0-4.5$ and low dissolved solids with poorly buffered stream water having $\mathrm{pH} 6.0-6.5$

and high sulfate. The storm runoff is derived from acidic rainfall with minor contributions from pyrite-oxidation products and carbonate minerals (Olyphant et al. 1991).

Typically, the greatest changes in $\mathrm{SC}$ and $\mathrm{pH}$ occurred with the largest changes in stream flow (greatest dilution by 

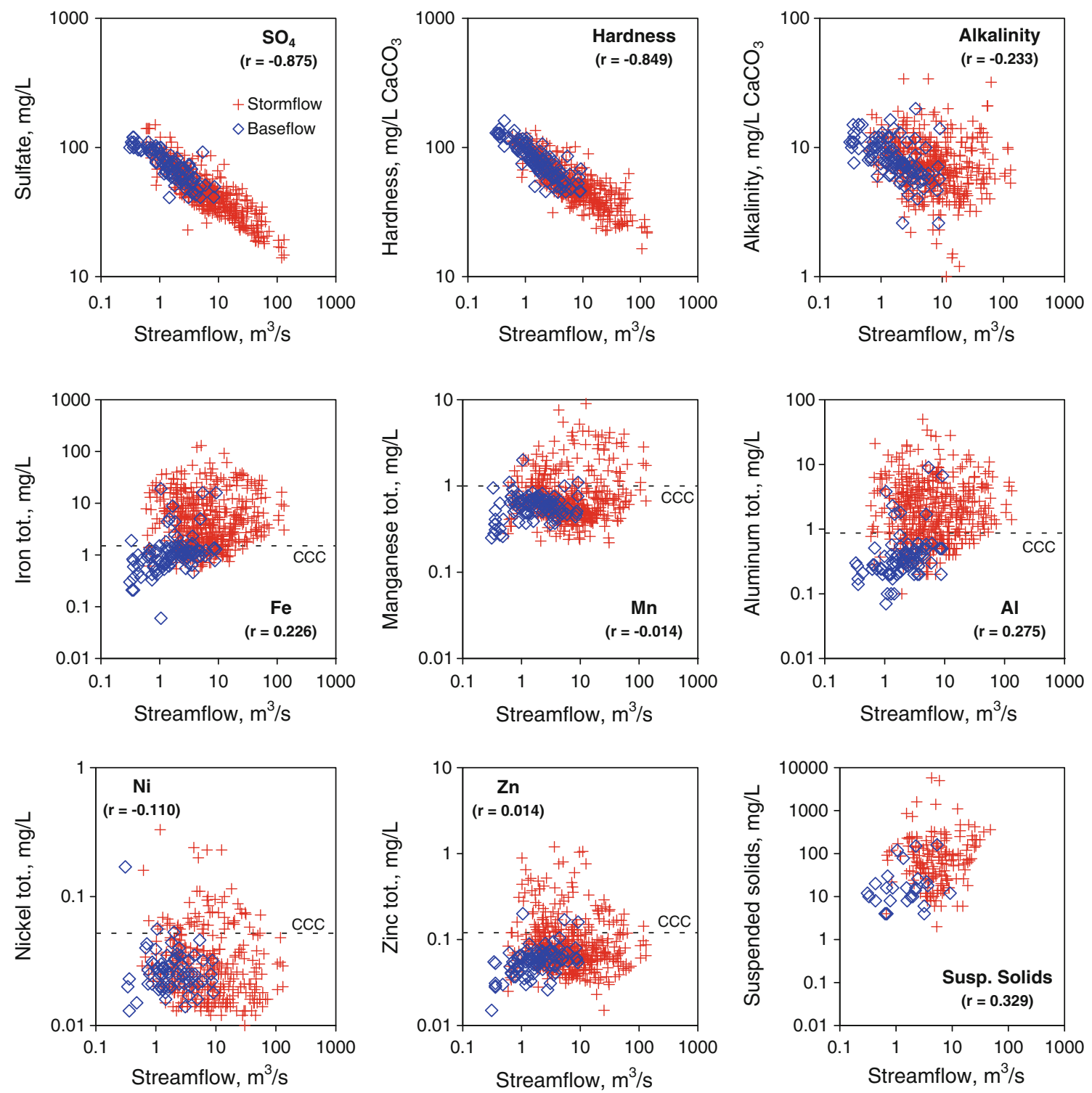

Fig. 9 Relations between streamflow and concentrations of waterquality constituents in base flow (open diamond symbol) and stormflow (cross symbol) samples, Swatara Creek at Ravine, PA. Hardness was computed from dissolved $\mathrm{Ca}$ and $\mathrm{Mg}$ in milligrams per liter $\left(2.5 \mathrm{C}_{\mathrm{Ca}}+4.1 \mathrm{C}_{\mathrm{Mg}}\right)$. Spearman rank correlation coefficient, $r$; values $>0.138$ or $<-0.138$ are significant $(p<0.001)$. Dashed

storm runoff). The minimum SC typically occurred with peak stream flow, whereas the minimum $\mathrm{pH}$ lagged by several hours, generally occurring during the falling stage. In contrast, concentrations of suspended solids generally increased to peak values during the initial rising stage and decreased prior to peak stage. Although the concentration of total iron included contributions from suspended particles, peaks for total iron tended to be achieved after the peaks for suspended solids, possibly reflecting a time lag for iron-laden water and associated sediment from the upper, mined part of the watershed to reach Ravine. horizontal lines, except for Mn, indicate criteria continuous concentration (CCC) values for protection of freshwater aquatic organisms (US Environmental Protection Agency 2002); dashed lines for Mn indicate PaDEP standard for daily mean concentration (Commonwealth of Pennsylvania 2002)

Generally, concentrations of suspended solids and total iron and other metals at a given stream flow during a storm event were greater during the rising stage than the falling stage (Fig. 8). This 'hysteresis' effect can be explained as resulting from the accumulation of metal-rich sediments ( $\mathrm{Fe}^{\mathrm{III}}, \mathrm{Mn}^{\mathrm{III}-\mathrm{IV}}$, and $\mathrm{Al}$ oxyhydroxides and clay minerals) within the streambed during base-flow conditions, scour and transport of the streambed deposits during rising storm flow stage, and dilution during falling stages. Small storm events can scour metal-rich sediments from the streambed with little dilution of the concentrations, resulting in 
concentrations of total metals and suspended solids that are comparable with or greater than those of large storms. Storm flow hysteresis patterns indicated for Swatara Creek and other streams can be affected by preceding conditions, with large peak concentrations following relatively stable base flow and diminished peak concentrations during succeeding storms of the same magnitude (Bowes et al. 2005; Caruso 2005).

Because of the hysteresis effect, stream flow and concentrations of metals in Swatara Creek at Ravine were poorly correlated (iron and aluminum) or not correlated (manganese, nickel, zinc) (Fig. 9). However, concentrations of total metals were strongly correlated with the concentration of suspended solids (Cravotta and Bilger 2001). The correlations between concentrations of suspended solids and total metals are consistent with suspended solids that contained approximately $10 \%$ iron, $5 \%$ aluminum, and lesser amounts of manganese and trace metals, which were the reported concentrations in fine streambed sediments in the study area (Cravotta and Bilger 2001).

Concentrations of aluminum, nickel, zinc, and other trace metals commonly were detected in the unfiltered samples but not in the corresponding filtered samples. Hence, the 'dissolved' chemical concentrations did not include substantial contributions from $<0.45 \mu \mathrm{m}$ colloids (e.g. Schemel et al. 2000). Furthermore, when detected in both unfiltered and filtered samples, the total concentrations of iron and aluminum, and, to a lesser extent, manganese, nickel, and zinc, commonly exceeded those in filtered samples (Fig. 10) indicating a major fraction of these metals was associated with suspended particles. In contrast, equivalent values for total and dissolved concentrations of manganese, nickel, and zinc frequently were reported in base-flow samples (Fig. 10), indicating that a major fraction of these metals was transported as dissolved ions and, possibly, fine colloids that could pass through filters.

\section{Water-Quality Trends}

The interpretation of trends in concentrations and loads of chemicals collected at different time intervals was complicated by changes in stream flow and associated effects on the $\mathrm{pH}$ and chemical concentrations. Although the annual stream flow and annual loads for all chemicals changed in
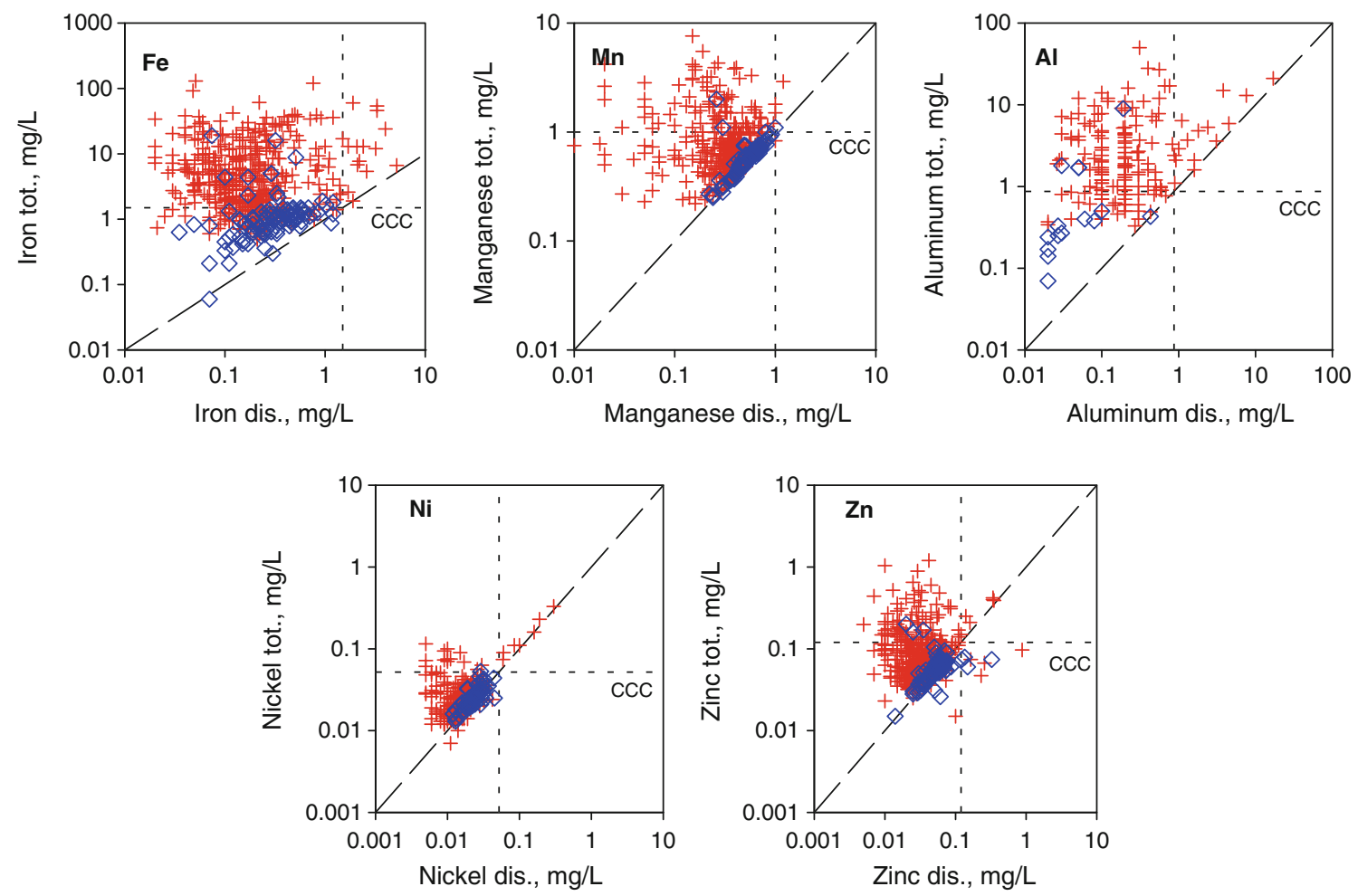

Fig. 10 Relations among concentrations of dissolved and total metals in stream water sampled during base-flow (open diamond symbol) and stormflow (cross symbol) conditions, Swatara Creek at Ravine, PA. Values farther to right of diagonal line indicate decreasing fraction of dissolved ions $(<0.45 \mu \mathrm{m})$ contributing to total concentration. Data plotted only if total and dissolved concentration above limit of

detection. Dotted horizontal and vertical lines, except for manganese, indicate criteria continuous concentration (CCC) values for protection of freshwater aquatic organisms (US Environmental Protection Agency 2002); dotted lines for manganese indicate PaDEP standard for daily mean concentration (Commonwealth of Pennsylvania 2002) 
parallel, during the study period, the flow- weighted concentration (FWC) values for different chemicals exhibited temporal variations not correlated with stream flow (Fig. 11). For Swatara Creek at Ravine, the FWC values for hydrogen ion, alkalinity, and dissolved iron had similar trends, decreasing from high values during 1997-1998 to minimum values in 2001-2003 and then increasing during 2003-2006. In contrast, FWC values for manganese and, to a lesser extent, sulfate exhibited possible downward trends, whereas those for dissolved aluminum were more erratic.

For Swatara Creek at Newtown, FWC estimates were computed for the sites upstream (\#0157155010) and downstream (\#0157155014) of limestone diversion wells using the stream flow record from the downstream site (Fig. 12). During 1997-2003, the FWC values for hydrogen ion and metals were lower and those for alkalinity were
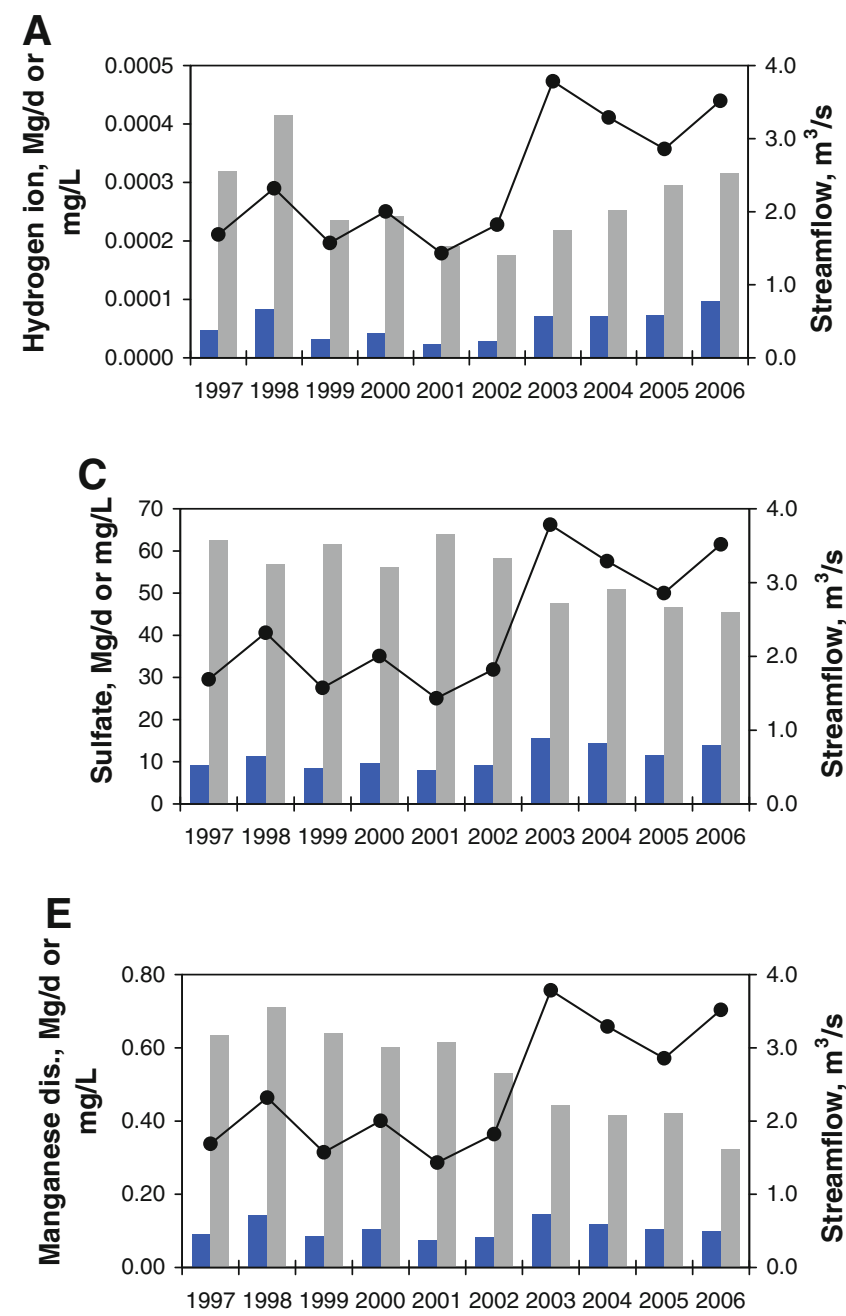

Fig. 11 Annual mean streamflow for Swatara Creek at Ravine (01571820; black line) and corresponding "calendar year loading" [CYL; left bar, units $\mathrm{Mg} / \mathrm{d}$ (megagrams per day)] and "flow-weighted concentration" (FWC; right bar, units $\mathrm{mg} / \mathrm{L}$ ) of chemicals associated higher at the downstream site compared to the upstream site. These differences in water quality between the two sites were expected because of the continuous addition of alkalinity and pulverized limestone to the stream by the diversion wells. However, the diversion wells were damaged by storms associated with Hurricane Ivan in September 2004 and were not operated continuously thereafter. After 2004, the FWC values for hydrogen ion increased and those for alkalinity decreased at the downstream site, while differences between the FWC values at the two sites became smaller for dissolved iron and manganese.

Flow-adjusted trends, which are identical for concentration and load of the particular chemical, were expressed as percent change between the 1997 start time and 2006 end time (period of continuous stream flow record). Flowadjusted trends for Swatara Creek at Ravine (Fig. 13)
B
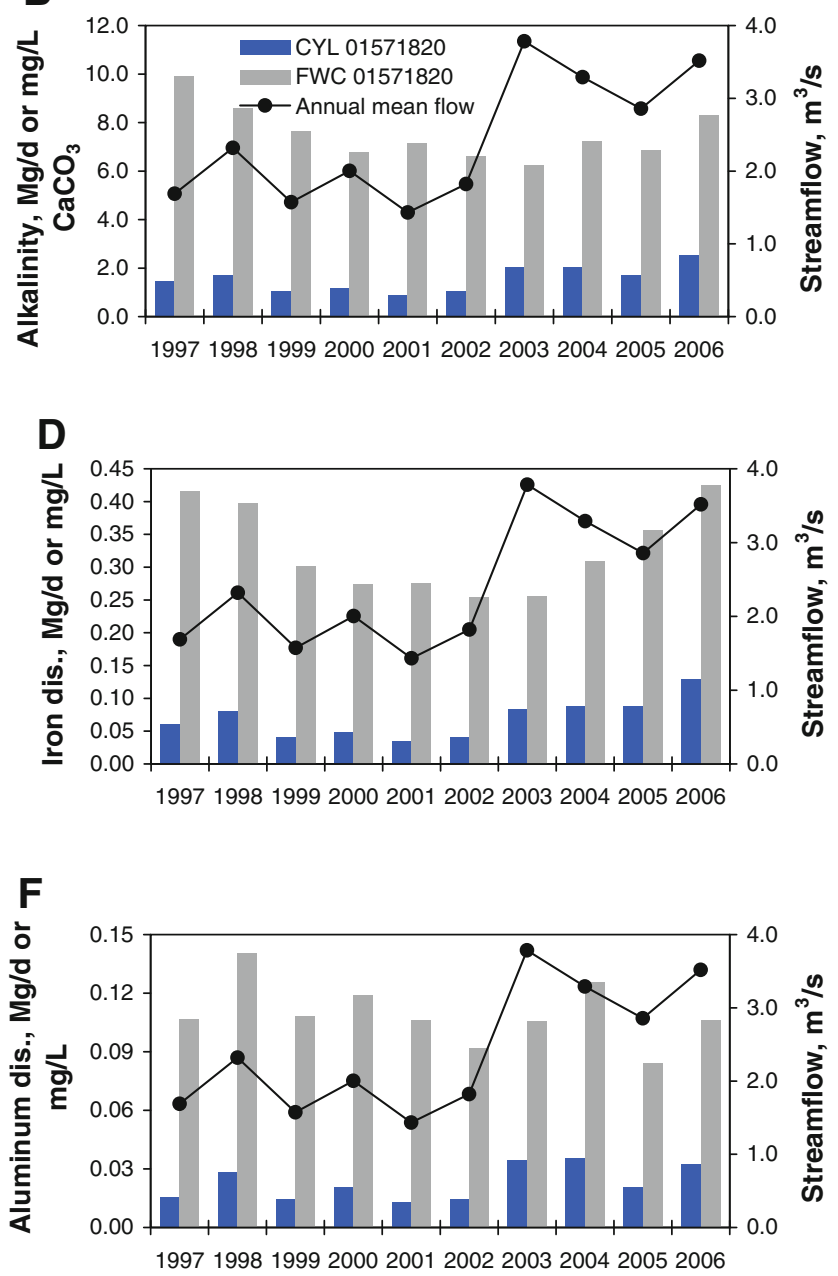

with mine effluent, 1997-2006: a, hydrogen ion; b, alkalinity; c, sulfate; d, dissolved iron; e, dissolved manganese; f, dissolved aluminum 
A
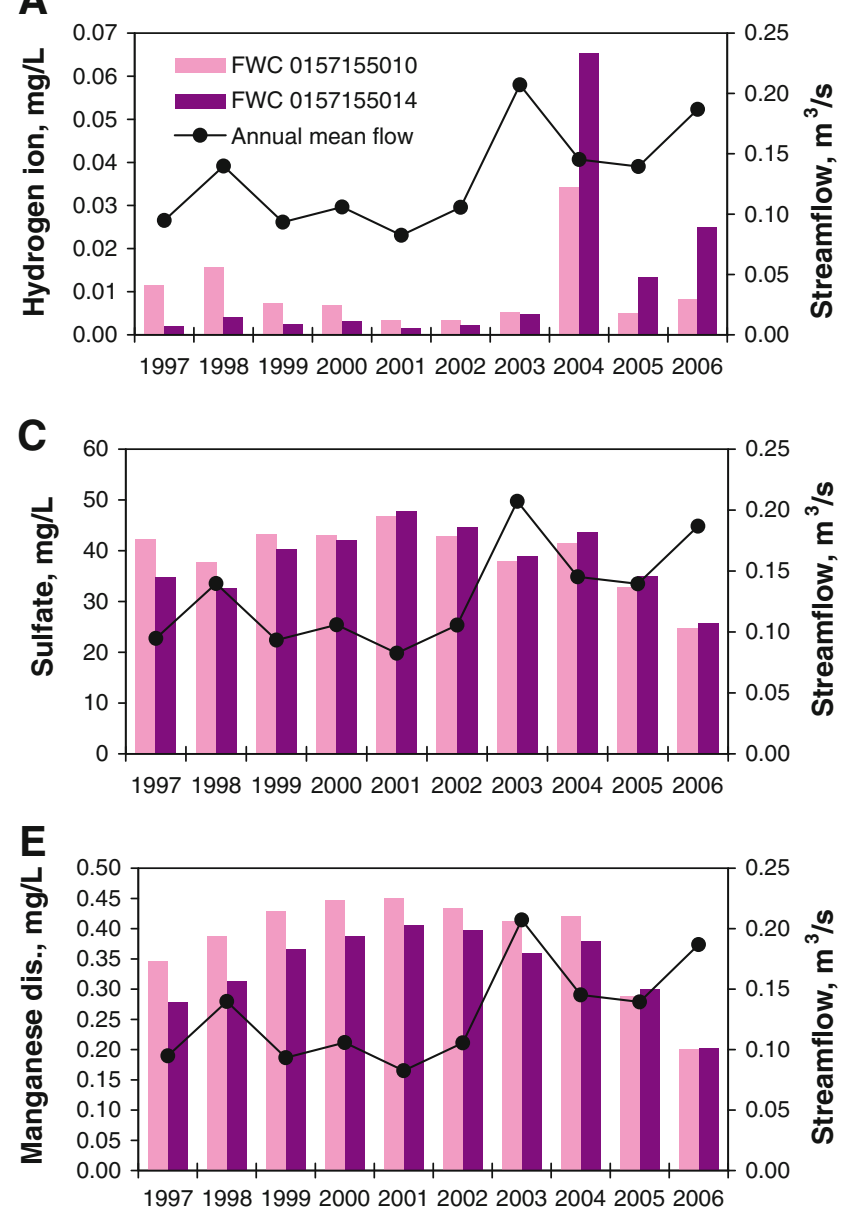

Fig. 12 Annual mean streamflow for Swatara Creek at Newtown (0157155014; black bar) and corresponding flow-weighted concentration (FWC) of chemicals upstream (0157155010; left bar) and

indicated significant decreases in hydrogen ion, dissolved and total manganese, total iron, and dissolved aluminum; no change in alkalinity, sulfate, or dissolved iron; and increases in calcium. The lack of trend in sulfate indicates that the AMD contaminant loading rate was unchanged during the study. The decrease in hydrogen ion and increase in calcium could result from the dissolution of limestone in various AMD treatment systems. Although generated by limestone dissolution, the lack of trend in alkalinity could indicate alkalinity was consumed during neutralization reactions that buffered the $\mathrm{pH}$ to be near neutral. Combined with decreases in iron, manganese, and aluminum, these flow-adjusted trends support the hypothesis that AMD treatment has increased $\mathrm{pH}$ and decreased the transport of dissolved metals during the study.

\section{Ecological Ramifications}

The increase in fish populations of Swatara Creek and its tributaries during the late 1990s coincided with the
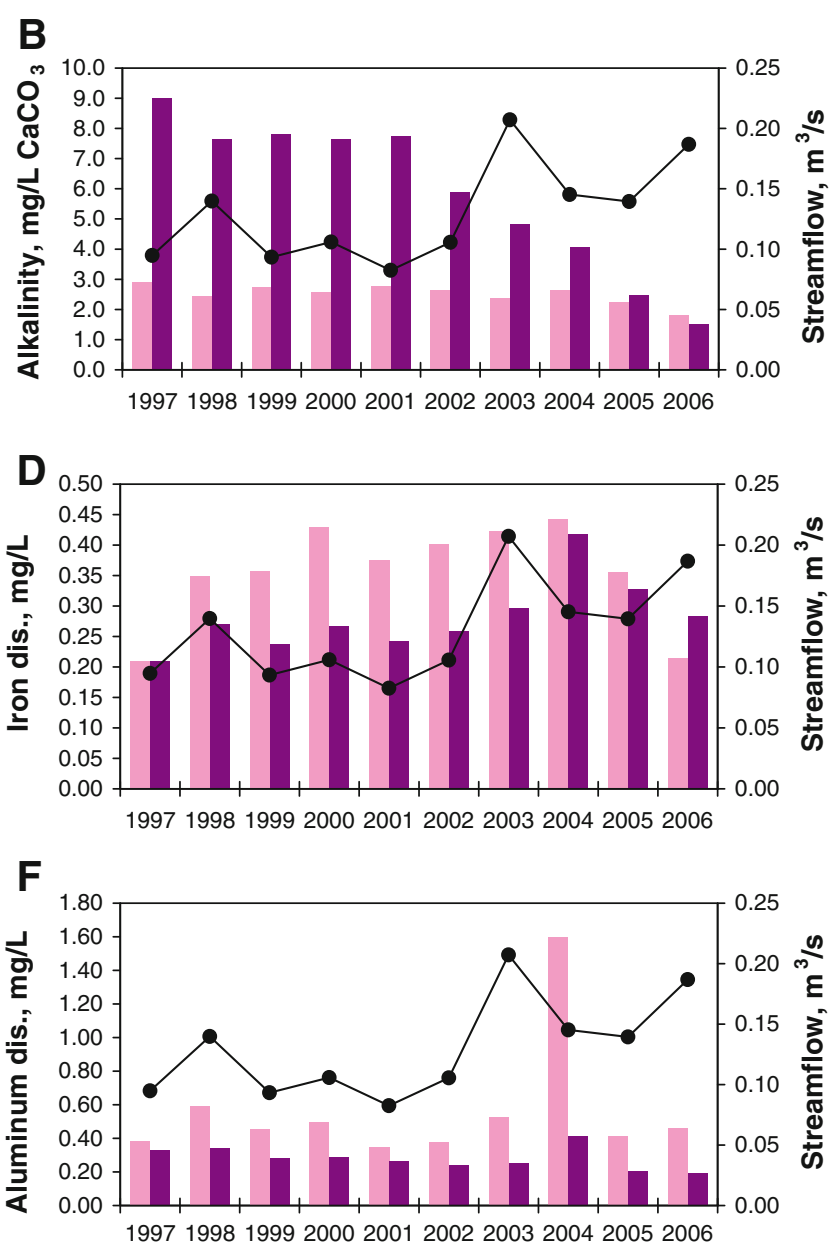

downstream (0157155014; right bar) of diversion wells, 1997-2006: a, hydrogen ion; b, alkalinity; c, sulfate; d, dissolved iron; e, dissolved manganese; $\mathbf{f}$, dissolved aluminum

implementation of limestone-based treatment systems at many of the AMD sources (Fig. 1b). Possible effects of such treatments include increased concentrations of calcium and alkalinity with associated buffering of $\mathrm{pH}$ to be near neutral, which could benefit fish and other aquatic organisms that are intolerant of low $\mathrm{pH}$ and sensitive to toxic metals. Because of solubility and adsorption, the concentrations of dissolved metals would tend to decrease with increased pH (Cravotta 2008; Webster et al. 1998), plus added calcium and alkalinity may be important in mitigating toxic effects of metals (Di Toro et al. 2001; Paquin et al. 2000; Yan et al. 2003). The protective effect of calcium can result from competition between $\mathrm{Ca}^{2+}$ and the free metal ion $\left(\mathrm{Cu}^{2+}, \mathrm{Cd}^{2+}, \mathrm{Pb}^{2+}, \mathrm{Ni}^{2+}, \mathrm{Zn}^{2+}\right)$ for binding sites on the gill or other sites of toxic action (commonly termed 'biotic ligand'), whereas the protective effect of alkalinity can result from the formation of metalbicarbonate complexes that render the free metal ion unavailable for biological uptake (Balistrieri and Blank 2008; Mager et al. 2010). 


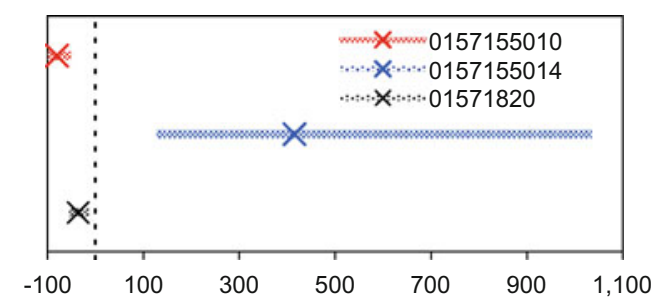

Hydrogen ion, percent change during 1997-2006
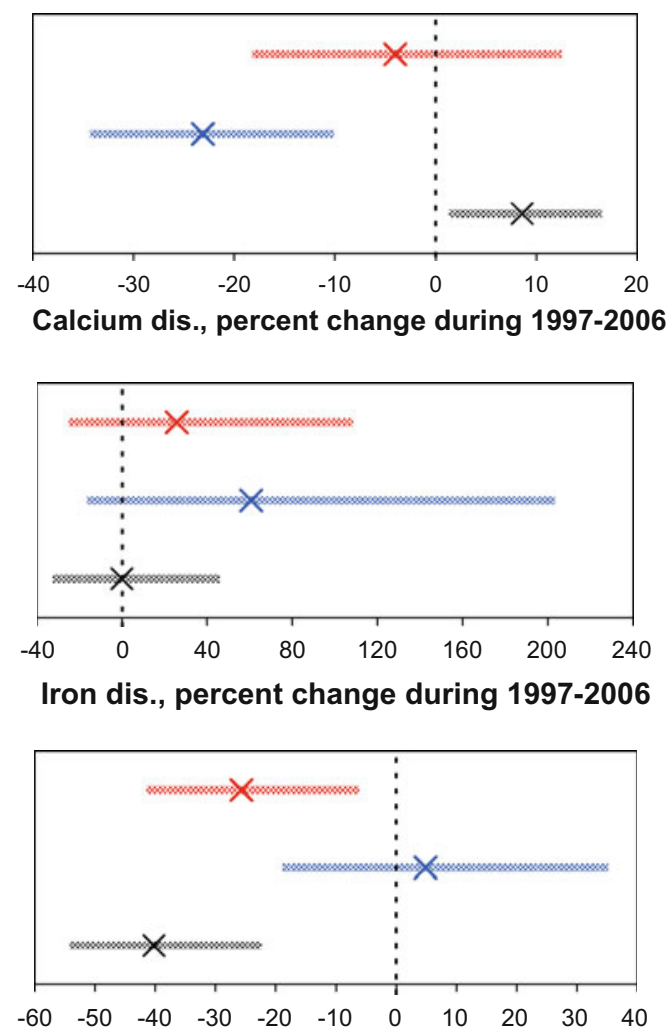

Manganese dis., percent change during 1997-2006

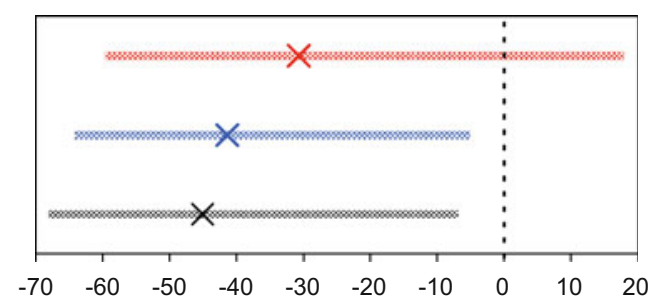

Aluminum dis., percent change during 1997-2006

Fig. 13 Estimated flow-adjusted trend (X) and confidence interval (CI) bar for chemicals in Swatara Creek at Ravine (01571820; lower black bar) and Swatara Creek at Newtown downstream (0157155014; middle blue bar) and upstream from diversion wells (0157155010;

To maintain its designated use as a cold-water fishery, Swatara Creek and other such streams in Pennsylvania must have DO concentrations greater than $5.0 \mathrm{mg} / \mathrm{L}$ at all times and temperatures less than $18.9^{\circ} \mathrm{C}$ during July and August (warmest months) (Commonwealth of Pennsylvania 2002).

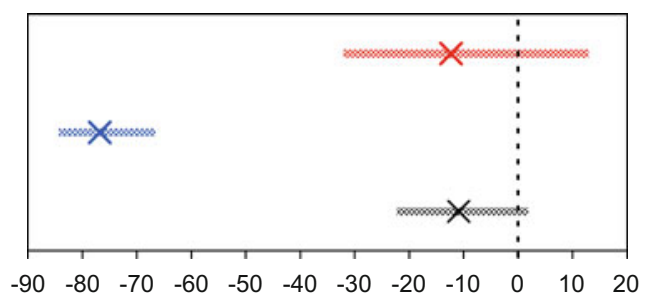

Alkalinity, percent change during 1997-2006

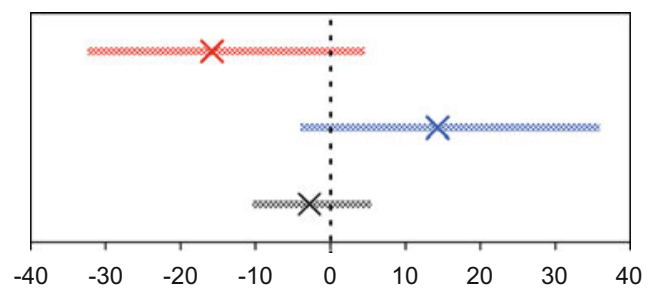

Sulfate dis., percent change during 1997-2006
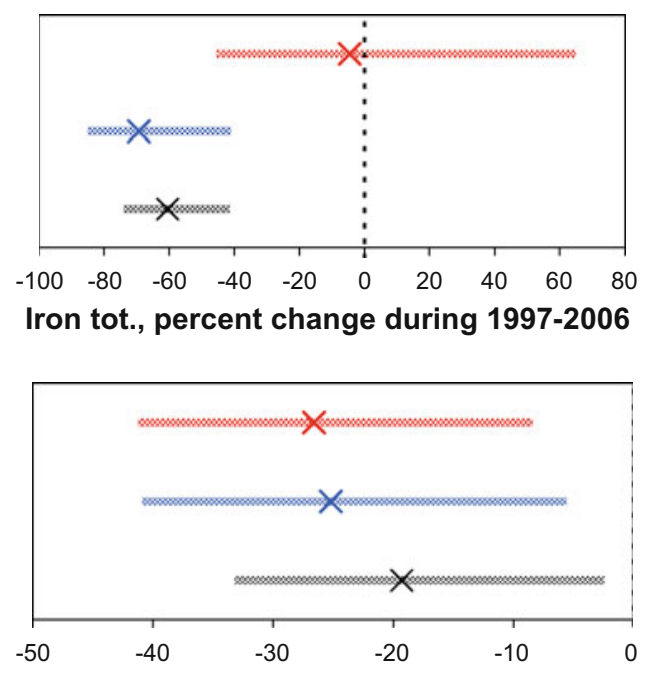

Manganese tot., percent change during 1997-2006

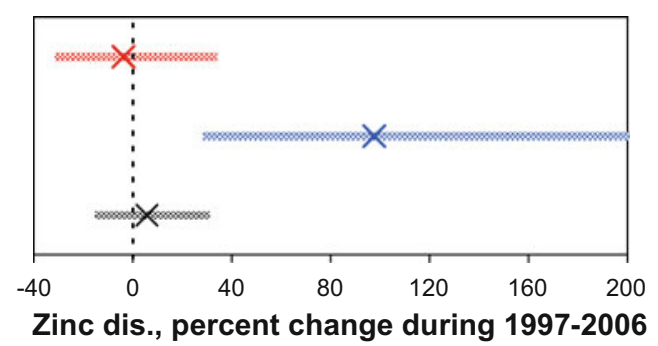

upper red bar), 1997-2006. If the CI is completely negative (downward trend) or completely positive (upward trend), the trend is significant

The minimum DO concentration at Ravine was $8.7 \mathrm{mg} / \mathrm{L}$ during July 1997 . However, the stream water temperature occasionally exceeded $18.9^{\circ} \mathrm{C}$ during low-flow conditions in summer (Figs. 2c, 5c), and concentrations of metals periodically exceeded water-quality criteria for protection 
of aquatic organisms (Figs. 9, 10). Although elevated temperatures can produce faster rates of iron oxidation and associated metals removal in AMD treatment systems, the prolonged exposure of stream water or AMD to ambient air temperatures or sunlight can produce temperature extremes that are not suitable for brook trout and other cold-water species.

The overall fish-community structure in Swatara Creek at Ravine could be characterized as transitional between cold-water and warm-water classifications. Although species abundance varied from year to year, the majority of the species collected during 1996-2006 was considered to have moderate tolerance to low $\mathrm{pH}$ and pollution (Table 1). Several of the fish taxa are intolerant of pollution and low $\mathrm{pH}$, such as river chub (Nocomis micropogon), longnose dace (Rhinichthys cataractae), northern hog sucker (Hypentelium nigricans), and shield darter (Percina peltata) (Table 1). As the maximum stream temperature increased during summer months (Figs. 2c, 5c), competition between cold- and warm-water species could have been a factor affecting species abundance. For example, at Ravine during 1997-1998, cold- and cool-water species predominated, including blacknose dace, creek chub (Semotilus atromaculatus), fallfish (Semolitus corporalis), white sucker, brook trout, and tessellated darter (Etheostoma olmstedi) (Table 1). In 1999, cool-water species including smallmouth bass (Micropterus dolomieu), river chub (Nocomis micropogon), and fallfish were dominant, with substantially fewer blacknose dace, tessellated darter, and brook trout. Likewise, when rock bass, a warm-water species, were abundant in 2003 and 2006, the number of brook trout greatly diminished, possibly reflecting variations in stream flow during the survey in addition to the variations in maximum stream temperature (Fig. 2). As observed elsewhere (Snucins and Gunn 2003), the range expansion of smallmouth bass and associated warm-water fish could be an important factor affecting food-web structure and the recovery of trout and associated coldwater fish in acid-stressed systems.

Base flow during the study met Commonwealth of Pennsylvania (2002) chemical water-quality standards; however, storm flow commonly did not meet $\mathrm{pH}$ standards (6.0-9.0) or concentrations of total iron $(1.5 \mathrm{mg} / \mathrm{L}$ daily mean), dissolved iron $(0.3 \mathrm{mg} / \mathrm{L}$ maximum $)$, and total manganese (1.0 mg/L maximum) (Figs. 9, 10). Furthermore, although concentrations of dissolved metals in filtered samples generally met US Environmental Protection Agency (US EPA) criteria continuous concentration (CCC) limits for protection of freshwater aquatic organisms, the concentrations of total metals in unfiltered storm flow samples (Figs. 9, 10) commonly exceeded CCC values for iron $(1.0 \mathrm{mg} / \mathrm{L})$ and aluminum $(0.087 \mathrm{mg} / \mathrm{L})$ and occasionally exceeded CCC values for nickel $(0.052 \mathrm{mg} / \mathrm{L})$ and zinc $(0.120 \mathrm{mg} / \mathrm{L})$ (US EPA 2002). The CCC limits indicate potential for adverse effects resulting from long-term (30 day) exposure. Although storm conditions lasting only hours to days accounted for most exceedances of waterquality criteria, impounding the storm water could prolong exposure (Fishel 1988). Decreased concentrations of sulfate, alkalinity, and hardness during storm flow conditions (Fig. 9) could increase the bioavailability of metals because of decreases in complexing ligands and competing cations $\left(\mathrm{Ca}^{2+}, \mathrm{Mg}^{2+}\right)$ (Balistrieri and Blank 2008; Mager et al. 2010).

Metal-rich suspended solids and streambed sediments represent a potential source of dissolved metals. Solid forms of the metals could be ingested by aquatic organisms with subsequent uptake of dissolved species within the gut. Dissolved metals also could be derived by recrystallization of metastable solid phases to more stable phases (Bigham and Nordstrom 2000), by dissolution or desorption (Francis et al. 1989; Webster et al. 1998), and/or by reductive dissolution of $\mathrm{Fe}^{\mathrm{III}}$ and $\mathrm{Mn}^{\mathrm{III}-\mathrm{IV}}$ oxides (Francis and Dodge 1990). These processes could be promoted by decreases in $\mathrm{pH}$ and/or redox potential in the streambed or water column.

Twenty-four of the 33 fish species identified in Swatara Creek at Ravine during the study had been previously reported for Pennsylvania streams with $\mathrm{pH}$ 4.6-6.4 (Table 1). A subset of these fish was found in Good Spring Creek at Tremont, Lorberry Creek at Lorberry Junction, and Swatara Creek at Newtown (Table 1). Concentrations of dissolved sulfate, iron, and manganese were greater for Lorberry Creek and Good Spring Creek than Swatara Creek at Ravine or Swatara Creek at Newtown (Fig. 3). Although Good Spring Creek and Lorberry Creek had fewer fish than Swatara Creek at Ravine, these sites had more fish than Swatara Creek at Newtown (Fig. 2). Such differences in fish numbers and species diversity reflect smaller stream flows and limited habitat at the upstream sites. Sections of the surveyed reach at Newtown flowed intermittently during the study. Greater species diversity and larger populations would be expected for larger aquatic habitats (Vannote et al. 1980). Although fish surveys were not conducted prior to 2002 for Lorberry Creek, potential downward trends in acidity and dissolved metals concentrations for Lorberry Creek during the study (Fig. 3) could explain the appearance of blacknose dace, creek chub, and brook trout in this tributary. These species, which are moderately tolerant of low $\mathrm{pH}$ and pollution (Table 1), were among the first species found in Swatara Creek at Ravine during 1996, indicating early stages of its ecological recovery. Similarly tolerant fish species have been identified as early colonists in other systems recovering from acidification (Cravotta 2005; Short et al. 1990).

Cravotta and Bilger (2001) presented results for macroinvertebrate surveys on Swatara Creek at Ravine 
conducted during 1996-2000. Although such data were not collected during 2001-2006, a macroinvertebrate survey of Swatara Creek at Ravine in September 2007 indicated results comparable to previous assessments (Gary Walters, Pennsylvania Dept of Environmental Protection 2008, written commun.). Although 11 benthic macroinvertebrate taxa (family level), including 3 genera of Ephemeroptera (mayflies) were found in Swatara Creek at Ravine in 2000, a few relatively pollution- tolerant taxa dominated. More than half of the individual specimens identified in 2000 were Hydropsyche and Chironomidae, which are tolerant of metals and acidic conditions (Courtney and Clements 2002; Short et al. 1990). The lack of taxa richness and trophic imbalance in Swatara Creek is consistent with the identified toxic effect levels for metals in the streambed sediments (Cravotta and Bilger 2001) and implies that metals in the aquatic environment that are stressful to macroinvertebrates may not be severely limiting to fish. Because native fish populations had returned, but the macroinvertebrate community continued to indicate waterquality impairment in 2007, Swatara Creek was characterized as "partially meeting designated uses" and was not removed from the proposed 2008 Pennsylvania 303(d) list of impaired waters (Pennsylvania Dept of Environmental Protection 2007).

\section{Summary and Conclusions}

Streams affected by AMD commonly have diminished fish populations because of low $\mathrm{pH}$ and/or elevated concentrations of iron, aluminum, and other metals from the AMD. However, as impacts from AMD become less severe through natural attenuation and/or watershed-restoration activities, fish populations may rebound. For example, upper Swatara Creek had been contaminated by AMD for most of the twentieth century. Because of progressive improvement in water quality after remedial work in 19952001 and the subsequent recovery of native fish populations, upper Swatara Creek was recently characterized as a "nonpoint-source success story."

More than four decades of intermittent monitoring of base flow of Swatara Creek immediately downstream from the mined area indicated median sulfate concentration decreased from about $150 \mathrm{mg} / \mathrm{L}$ in 1959 to $50 \mathrm{mg} / \mathrm{L}$ in 2007 while $\mathrm{pH}$ increased from acidic to near-neutral values (medians: $\mathrm{pH} \approx 4$ before 1975; $\mathrm{pH} \approx 6.5$ after 1995). These long-term trends probably resulted from a decrease in pyrite oxidation and the onset of carbonate buffering, because of flooding the mines during the early period and the dissolution of limestone in treatment systems during the later period. As a consequence of the improved water quality, fish populations in Swatara Creek rebounded from nonexistent during 1959-1990 to as many as 25 species during 1996-2006, including several taxa that are intolerant of low $\mathrm{pH}$ and pollution.

The study demonstrated that stream water quality improvement and the recovery of fish populations in Swatara Creek coincided with implementation of AMD treatments in the upper part of the Swatara Creek watershed during 1995-2001. The AMD treatments with limestone added alkalinity, which was needed to maintain near-neutral $\mathrm{pH}$, and calcium, which can be important to aquatic organisms for mitigating toxic effects of dissolved metals. Flow-adjusted trends for Swatara Creek at Ravine indicating decreases in hydrogen ion and metals and increases in calcium during 1997-2006 support the hypothesis that the AMD treatments helped to improve downstream aquatic quality. The treatments not only reduced the influence of AMD, but also mitigated fluctuations in $\mathrm{pH}$ associated with episodic acidification during storm events.

Sulfate concentration, SC, and $\mathrm{pH}$ of Swatara Creek at Ravine were inversely correlated with stream flow because of dilution of poorly buffered stream water with weakly acidic storm runoff. In contrast, total and dissolved concentrations of metals were poorly correlated with stream flow because concentrations of suspended solids and metals typically peak prior to peak stream stage (hysteresis). As a result of scour and transport of the metals in streambed sediments, concentrations of suspended solids and total metals in the water column are correlated, and those for storm flow typically exceed base flow.

Despite near-neutral, cool-water conditions in Swatara Creek that support a diverse fish population, untreated AMD and metal-rich streambed sediments represent a substantial, long-term source of metals. Although the transport of dissolved iron, aluminum, and most trace metals typically is attenuated at near-neutral $\mathrm{pH}$, transport of suspended metals persists in Swatara Creek, especially during storm flow conditions. Total iron, manganese, aluminum, and associated trace metals commonly increase in concentration at the onset of storm flow conditions; peak metal concentrations typically are achieved prior to peak discharge. The metal content of the suspended solids is relatively constant over the range of stream flow conditions, implying a relatively uniform source of material such as streambed deposits.

In general, temporal variations in water quality of loworder streams, such as the northern part of Swatara Creek, are difficult to characterize by routine monitoring at monthly or quarterly intervals. This routine works well to identify potential long-term trends but is not appropriate to characterize rapidly changing conditions in response to stream flow. Automated samplers and continuous water-quality and stream flow monitoring methods generally will indicate extremes, which can be important with respect to biological or regulatory thresholds, and can indicate significant 
relations between stream flow, water chemistry, and transport of sediment and associated chemicals. Such monitoring equipment, used in this study to document extremes during storm flow conditions, also could be used to document diurnal variations in water quality during stable base-flow conditions (e.g. Gammons et al. 2007). Water-quality regulations established to achieve in-stream water-quality standards or to maintain designated uses of the water body (water supply, fishing, etc.), such as total maximum daily loads (TMDLs), require baseline characterization of pollutant loads over a range of hydrologic conditions in order to determine required reductions in loading from various contaminant sources (Caruso 2005). Data that do not adequately represent storm flow conditions will underestimate the annual transport of sediment and associated metals.

Generally, limestone-based treatment systems may be effective to maintain stream $\mathrm{pH}$ in water bodies affected by AMD and subject to acidification during storms. Nevertheless, neutralization and $\mathrm{pH}$ buffering alone will not remedy the problem of metals transport. Solid forms of the metals, as particulate and particle coatings, can be ingested and accumulated by aquatic organisms and can be remobilized by reductive dissolution of $\mathrm{Fe}^{\mathrm{III}}$ and $\mathrm{Mn}^{\mathrm{III}-\mathrm{IV}}$ oxides in buried sediment. Additional measures such as wetlands and holding basins for storm water could be warranted to prevent metals transport to the stream. However, impounding water in wetlands and shallow ponds could increase warming of the water during summer, potentially leading to temperatures that are not favorable to fish. Thus, strategies for AMD treatment should be considered that minimize the potential for excessive warming of the water while removing toxic metals.

Although the study demonstrated that fish populations were affected by hydrochemical conditions during the weeks, months, and years prior to the annual surveys, specific hydrochemical thresholds critical to population recovery could not be identified. The potential for synergistic effects of toxic chemical constituents and for complexation of dissolved metals with inorganic ligands and organic carbon (not measured), combined with changes in water temperature complicate the interpretations of ecological stressors. Supplemental data on populations of fish and other aquatic organisms before and after extreme hydrologic events (droughts, storms) coupled with water-quality data, including inorganic constituents and organic carbon concentrations, for such events could be useful to establish relations between transient water-quality conditions and specific factors that could be limiting to aquatic organisms.

Acknowledgments This research was supported by the PaDEP and the Schuylkill Conservation District with funding through the US EPA Non-point Point Source National Monitoring Program, the US DOE, and the USGS Cooperative Water-Resources Program. The first author is grateful to Roger J. Hornberger and Daniel J. Koury of
PaDEP for their sustained support. Jeffrey J. Chaplin, Emily Eggler, Heather Eggleston, Katherine Tuers Brayton, Suzanne J. Ward, Jeffrey B. Weitzel, Kovaldas "KB" Balciauskas, Michael D. Bilger, and John Rote, presently or formerly at USGS, are acknowledged for critical assistance with field work and data processing. Although many individuals assisted during annual fish surveys, Robert Schott of PaDEP warrants special thanks for providing vital expertise and equipment for fish capture and identification during several years of the study. The authors also wish to acknowledge constructive reviews of the manuscript by Kevin J. Breen and Robert Runkel of USGS, John Arway of the Pennsylvania Fish and Boat Commission, Christopher H. Gammons of Montana Tech, and an anonymous reviewer. Any use of trade, firm, or product names is for descriptive purposes only and does not imply endorsement by the US Government.

\section{References}

American Public Health Association (1998a) Alkalinity (2320)/ Titration method. In: Clesceri LS, Greenberg AE, Eaton AD (eds) Standard methods for the examination of water and wastewater, 20th edn, American Public Health Association, Washington, DC, pp 2.26-2.30

American Public Health Association (1998b) Acidity (2310)/Titration method. In: Clesceri LS, Greenberg AE, Eaton AD (eds) Standard methods for the examination of water and wastewater, 20th edn, American Public Health Association, Washington, DC, pp 2.24-2.26

Baker JP, Schofield CL (1982) Aluminum toxicity to fish in acidic waters. Water Air Soil Poll 18:289-309

Balistrieri LS, Blank RG (2008) Dissolved and labile concentrations of $\mathrm{Cd}, \mathrm{Cu}, \mathrm{Pb}$, and $\mathrm{Zn}$ in the South Fork Coeur d'Alene River, Idaho-comparisons among chemical equilibrium models and implications for biotic ligand models. Appl Geochem 23:33553371

Barbour MT, Gerritsen J, Snyder BD, Stribling JB (1999) Rapid bioassessment protocols for use in streams and wadeable riversperiphyton, benthic macroinvertebrates, and fish. 2nd edn, US EPA 841-B-99-002, www.epa.gov/OWOW/monitoring/techmon. html

Berg TM, Barnes JH, Severn WD, Skema VK, Wilshusen JP, Yannaci DS (1989) Physiographic provinces of Pennsylvania. Pennsylvania Geol Surv Map 13, scale 1:2,000,000, Harrisburg, PA, USA

Bigham JM, Nordstrom DK (2000) Iron and aluminum hydroxysulfate minerals from acid sulfate waters. In: Jambor JL, Alpers CN, Nordstrom DK (eds) Sulfate minerals, crystallography, geochemistry and environmental significance, Mineralogical Soc of America Reviews in Mineralogy and Geochemistry 40: 351-403

Blowes DW, Ptacek CJ, Jambor JL, Weisener CG (2003) The geochemistry of acid mine drainage. In: Lollar BS (ed) Environmental geochemistry. Elsevier, Treatise on Geochemistry, Holland HD, Turekian KK (eds) vol 9, Elsevier-Pergamon, Oxford, UK, pp 149-204

Bowes MJ, House WA, Hodgkinson RA, Leach DV (2005) Phosphorus-discharge hysteresis during storm events along a river catchment: the River Swale, UK. Water Res 39:751-762

Broshears RE, Runkel RL, Kimball BA, McKnight DM, Bencala KE (1996) Reactive solute transport in an acidic stream-experimental $\mathrm{pH}$ increase and simulation of controls on $\mathrm{pH}$, aluminum, and iron. Environ Sci Technol 30:3016-3024

Butler RL, Cooper EL, Crawford JK, Hales DC, Kimmel WG, Wagner CC (1973) Fish and food organisms in acid mine waters of Pennsylvania. US EPA-R3-73-032, p 158

Cannon WE, Kimmel WG (1992) A comparison of fish and macroinvertebrate communities between an unpolluted stream 
and the recovery zone of a stream receiving acid mine drainage. J PA Acad Sci 66:58-62

Caruso BS (2005) Simulation of metals total maximum daily loads and remediation in a mining-impacted stream. J Environ Eng 131:777-789

Cleveland L, Buckler DR, Brumbaugh WG (1991) Residue dynamics and effects of aluminum on growth and mortality in brook trout. Environ Toxicol Chem 10:243-248

Cohn TA, DeLong LL, Gilroy EJ, Hirsch RM, Wells RM (1989) Estimating constituent loads. Water Resour Res 25:937-942

Commonwealth of Pennsylvania (2002) Chapter 93. Water quality standards. Pennsylvania Code, Title 25. Environmental Protection. Harrisburg, PA. Commonwealth of Pennsylvania, pp 93.193.226

Corbett ES, Lynch JA (1982) Rapid fluctuations in stream flow pH and associated water-quality parameters during a storm flow event. Proceedings of international symposium on hydrometeorology, American Water Resources Association, pp 461-464

Courtney LA, Clements WH (2002) Assessing the influence of water and substratum quality on benthic macroinvertebrate communities in a metal-polluted stream-an experimental approach. Freshw Biol 47:1766-1778

Cravotta CA III (2000) Relations among sulfate, metals, sediment, and stream flow data for a stream draining a coal-mined watershed in east-central Pennsylvania. Proceedings of 5th International Conference on Acid Rock Drainage (ICARD). Littleton, CO, USA, Soc for Mining, Metallurgy, and Exploration, Inc., vol 1, pp 401-410

Cravotta CA III (2005) Effects of abandoned coal-mine drainage on stream flow and water quality in the Mahanoy Creek Basin, Schuylkill, Columbia, and Northumberland Counties, Pennsylvania, 2001. US Geol Surv Scientif Investigat Rept 2004-5291, p 60

Cravotta CA III (2008) Dissolved metals and associated constituents in abandoned coal-mine discharges, Pennsylvania, USA: 2. Geochemical controls on constituent concentrations. Appl Geochem 23:203-226

Cravotta CA III (2010) Abandoned mine drainage in the Swatara Creek Basin, Southern Anthracite Coalfield, Pennsylvania, USA: 2. Performance of passive-treatment systems. Mine Water Environ (this volume)

Cravotta CA III, Bilger MD (2001) Water-quality trends for a stream draining the Southern Anthracite Field, Pennsylvania. Geochem Explor Environ Anal 1:33-50

Cravotta CA III, Kirby CS (2004) Effects of abandoned coal-mine drainage on stream flow and water quality in the Shamokin Creek Basin, Northumberland and Columbia Counties, Pennsylvania, 1999-2001. US Geol Surv Water-Resour Inv Rep 03-4311, p 58

Di Toro DM, Allen HE, Bergman HL, Meyer JS, Paquin PR, Santore RC (2001) A biotic ligand model of the acute toxicity of metals. I. Technical basis. Environ Toxicol Chem 20:2383-2396

Dsa JV, Johnson KS, Lopez D, Kanuckel C, Tumulinson J (2008) Residual toxicity of acid mine drainage- contaminated sediment to stream macroinvertebrates-relative contribution of acidity vs. metals. Water Air Soil Pollut 194:185-197

Eggleston JR, Kehn TM, Wood GH Jr (1999) Anthracite. In: Schultz $\mathrm{CH}$ (ed) The geology of Pennsylvania. PA Geological Survey. 4th series, Special Publ 1, pp 458-469

Fishel DK (1988) Preimpoundment hydrologic conditions in the Swatara Creek (1981-1984) and estimated postimpoundment water quality in and downstream from the planned Swatara State Park reservoir, Lebanon and Schuylkill Counties, PA. US Geol Surv Water-Resour Inv Rept 88-4087, p 108

Francis AJ, Dodge DJ (1990) Anaerobic microbial remobilization of toxic metals coprecipitated with iron oxide. Environ Sci Technol 24:373-378
Francis AJ, Dodge DJ, Rose AW, Ramirez AJ (1989) Aerobic and anaerobic microbial dissolution of toxic metals from coal wastes-mechanism of action. Env Sci Technol 23:435-441

Gammons CH, Milodragovich L, Belanger-Woods J (2007) Influence of diurnal cycles on monitoring of metal concentrations and loads in streams draining abandoned mine lands: an example from High Ore Creek, Montana. Environ Geol 53:611-622

Gannett Fleming Corddry and Carpenter, Inc. (1972) Swatara Creek mine drainage abatement project, part 1, Operation Scarlift: Commonwealth of Pennsylvania SL-126-1, p 57

Growitz DJ, Reed LA, Beard MM (1985) Reconnaissance of mine drainage in the coal fields of eastern Pennsylvanian. US Geol Surv Water-Resour Inv Rept 83-4274, p 54

Havas M, Rosseland BO (1995) Response of zooplankton, benthos, and fish to acidification-an overview. Water Air Soil Pollut $85: 51-62$

Helsel DR, Hirsch RM (2002) Statistical methods in water resources. US Geol Surv Techniques of Water- Resources Investigations 04-A3, p 523

Henry TB, Irwin ER, Grizzle JM, Wildhaber ML, Brumbaugh WG (1999) Acute toxicity of an acid mine drainage mixing zone to juvenile bluegill and largemouth bass. T Am Fish Soc 128:919928

Herlihy AT, Kaufmann PR, Mitch ME, Brown DD (1990) Regional estimates of acid mine drainage impact on streams in the midAtlantic and southeastern United States. Water Air Soil Pollut 50:91-107

Herricks EE (1977) Recovery of streams from chronic pollutional stress-acid mine drainage. In: Cairns J Jr, Dickson KL, Herricks EE (eds) Recovery and restoration of damaged ecosystems. Univ Press of Virginia, Charlottesville, pp 43-71

Jackson LR (1987) Swatara Creek, subbasin 07, subsubasin D (river miles 58.25 to 4.6). Pennsylvania Fish and Boat Commission Stream Survey Report, July 15, 1987

Johnson DB, Hallberg KB (2005) Acid mine drainage remediation options: a review. Sci Total Environ 338:3-14

Kirby CS, Cravotta CA III (2005) Net alkalinity and net acidity 2: practical considerations. Appl Geochem 20:1941-1964

Langland MJ, Raffensperger JP, Moyer DL, Landwehr JM, Schwarz GE (2006) Changes in stream flow and water quality in selected nontidal basins in the Chesapeake Bay watershed, 1985-2004. US Geol Surv Scientif Investigat Rept 2006-5178, p 75

MacDonald DD, Ingersoll CG, Berger TA (2000) Development and evaluation of consensus-based sediment quality guidelines for freshwater ecosystems. Arch Environ Con Tox 39:20-31

Mager EM, Brix KV, Grosell M (2010) Influence of bicarbonate and humic acid on effects of chronic waterborne lead exposure to the fathead minnow (Pimephales promelas). Aquatic Toxicol 96:135-144

McCarren EF, Wark JW, George JR (1964) Water quality of the Swatara Creek Basin. US Geol Surv Open-File Rept, Pa, p 88

Monteith DT, Hildrew AG, Flower RJ, Raven PJ, Beaumont WRB, Collen P, Kreiser AM, Shilland EM, Winterbottom JH (2005) Biological responses to the chemical recovery of acidified fresh waters in the UK. Environ Pollut 137:83-101

Nelson SM, Roline RR (1996) Recovery of a stream macroinvertebrate community from mine drainage disturbance. Hydrobiologia 339:73-84

Nordstrom DK (2000) Advances in the hydrochemistry and microbiology of acid mine waters. Int Geol Rev 42:499-515

Olyphant GA, Bayless ER, Harper D (1991) Seasonal and weatherrelated controls on solute concentrations and acid drainage from a pyritic coal-refuse deposit in southwestern Indiana, USA. J Contam Hydrol 7:219-236 
Paquin PR, Santore RC, Wu KB, Kavvadas CD, Di Toro DM (2000) The biotic ligand model - a model of the acute toxicity of metals to aquatic life. Environ Sci Policy 3:S175-S182

Pennsylvania Dept of Environmental Protection (2004) Watershed restoration action strategy (WRAS), State water plan subbasin 07D Swatara Creek watershed, Dauphin, Lebanon, Berks, and Schuylkill Counties. PA Department of Environmental Protection (DEP), Bureau of Watershed Mgmt, Harrisburg, PA, p 47, http://www.depweb.state.pa.us/watershedmgmt/lib/watershed $\mathrm{mgmt} /$ nonpoint_source/wras/wras-07d.pdf

Pennsylvania Dept of Environmental Protection (2007) 2006 Pennsylvania integrated water quality monitoring and assessment reportclean water act section 305(b) report and 303(d) list. PA DEP, Bureau of Watershed Mgmt, Harrisburg, PA, USA, p 55, http:// www.depweb.state.pa.us/watersupply/lib/watersupply/Master Narrative.pdf

Pennsylvania Dept of Environmental Protection (2009) Recreational use loss estimates for PA streams degraded by AMD 2006. Bureau of Abandoned Mine Reclamation acid mine drainage setaside program-program implementation guidelines, PA DEP Bureau of Abandoned Mine Reclamation, Harrisburg, PA, USA, p C1-C14, http://www.depweb.state.pa.us/portal/server.pt/com munity/abandoned_mine_reclamation/13961

Raymond PA, Oh N-H (2009) Long-term changes of chemical weathering in rivers heavily impacted from acid mine drainage: insights on the impact of coal mining on regional and global carbon and sulfur budgets. Earth Planet Sci Lett 284:50-56

Rutledge AT (1998) Computer programs for describing the recession of ground-water discharge and for estimating mean ground-water recharge and discharge from stream flow data-update. US Geol Surv Water-Resour Inv Rept 98-4148, p 43

Schemel LE, Kimball BA, Bencala KE (2000) Colloid formation and metal transport through two mixing zones affected by acid mine drainage near Silverton, Colorado. Appl Geochem 15:10031018

Shoemaker ME (1932) Swatara Creek, Schuylkill County. Pennsylvania Fish and Boat Commission Stream Survey Report, Harrisburg

Short TM, Black JA, Birge WJ (1990) Effects of acid-mine drainage on the chemical and biological character of an alkaline headwater stream. Arch Environ Con Tox 19:241-248

Snucins E, Gunn JM (2003) Use of rehabilitation experiments to understand the recovery dynamics of acid-stressed fish populations. Ambio 32:240-243

Steiner L (2000) Pennsylvania fishes. Pennsylvania Fish and Boat Commission, Harrisburg, $170 \mathrm{pp}$
Stuart WT, Schneider WJ, Crooks JW (1967) Swatara Creek Basin of southeastern Pennsylvania-an evaluation of its hydrologic system. USGS Water-Supply Paper 1829, p 79

U.S. EPA (2002) National recommended water quality criteria-2002. US Environmental Protection Agency 822-R-02-047, p 33

U.S. EPA (2007) Section 319 nonpoint source success storiesPennsylvania: Swatara Creek. US Environmental Protection Agency 841-F-07-001P, p 2, http://www.epa.gov/owow/nps/ Success319/state/pdf/pa_swatara.pdf

USGS (variously dated) USGS annual hydrologic data reports of Pennsylvania-Swatara Creek Basin and Swatara Creek project. US Geological Survey PA Water Science Center, http://pa. water.usgs.gov/ar/index.html

Vannote RL, Minshall GW, Cummins KW, Sedell JR, Cushing CE (1980) The river continuum concept. Can J Fish Aquat Sci 37:130-137

Vrba J, Kopacek J, Fott J, Kohout L, Nedbalova L, Prazakova M, Soldan T, Schaumburg J (2003) Long- term studies (1871-2000) on acidification and recovery of lakes in the Bohemian Forest (central Europe). Sci Total Environ 310:73-85

Webster JG, Swedlund PJ, Webster KS (1998) Trace metal adsorption onto an acid mine drainage iron(III) oxy hydroxy sulfate. Environ Sci Tech 32:1361-1368

Winland RL, Traina SJ, Bigham JM (1991) Chemical composition of ochreous precipitates from Ohio coal mine drainage. J Environ Qual 20:452-460

Wolkersdorfer C, Bowell RJ (eds) (2004) Contemporary reviews of mine water studies in Europe, part 1. Mine Water Environ 23: $162-182$

Wood CR (1996) Water quality of large discharges from mines in the anthracite region of eastern Pennsylvania. USGS Water-Resour Inv Rept 95-4243, p 69

Wood GH Jr, Kehn TM, Eggleston JR (1986) Deposition and structural history of the Pennsylvania Anthracite region. In: Lyons, PC, Rice, CL (eds) Paleoenvironmental and Tectonic Controls in Coal-forming Basins of the United States. Geol Soc America Special Paper 210: 31-47

Yan ND, Leung B, Keller W, Arnott SE, Gunn JM, Raddum GG (2003) Developing conceptual frameworks for the recovery of aquatic biota from acidification. Ambio 32:165-169

Ziemkiewicz PF, Skousen JG, Simmons J (2003) Long-term performance of passive acid mine drainage treatment systems. Mine Water Environ 22:118-129 